U.S. Department of the Interior

U.S. Geological Survey

\title{
Simulation of Streamflow, Middle Humboldt River, North-Central Nevada
}

Water-Resources Investigations Report 01-4231

Prepared in cooperation with the

NEVADA DIVISION OF WATER RESOURCES

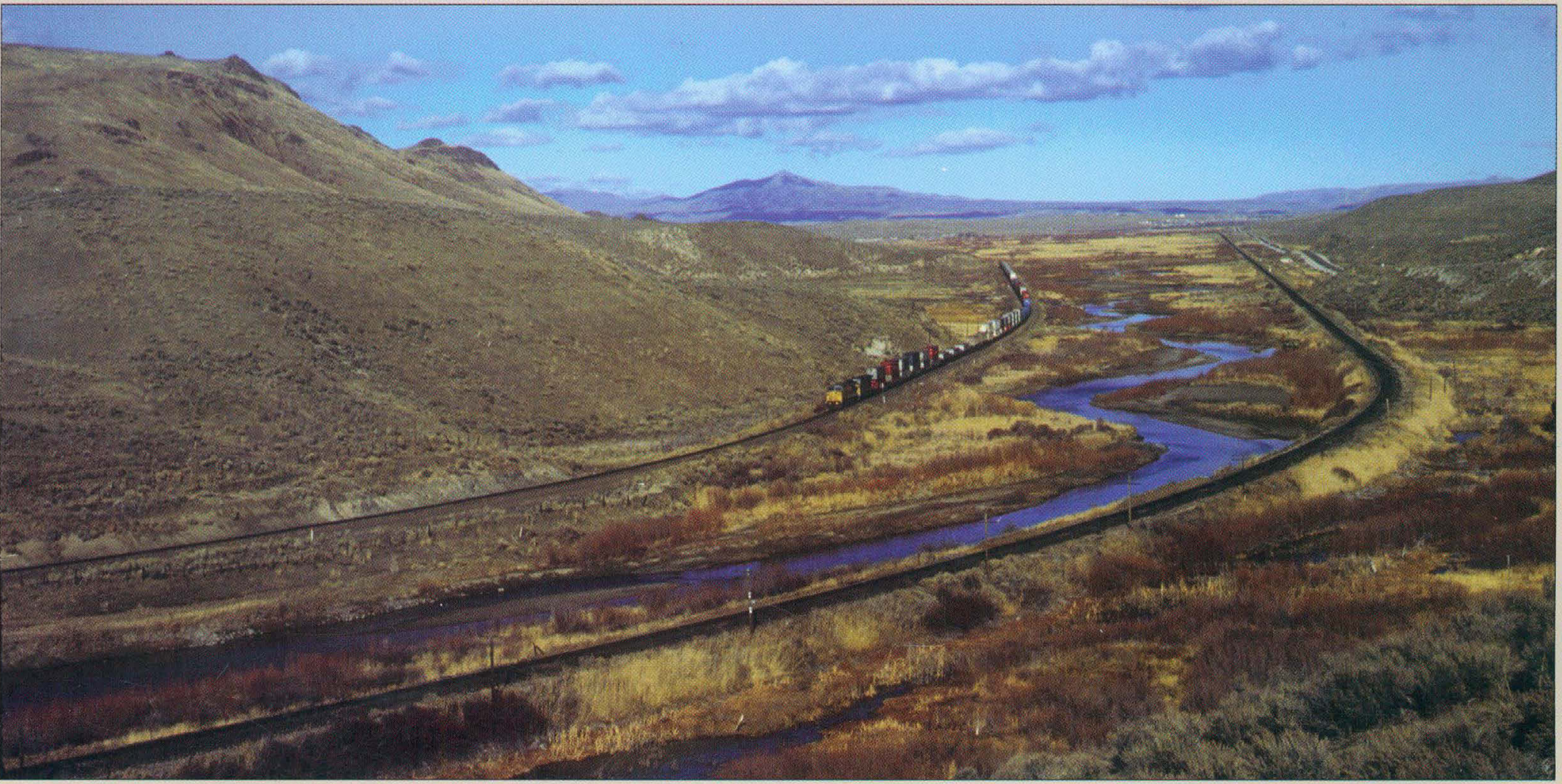


COVER PHOTOGRAPH: Humboldt River about 10 miles downstream from Carlin, Nev., and 8 miles upstream from Palisade, Nev., December 1996, looking northeast. Photograph by Russell W. Plume, U.S. Geological Survey

BACK COVER TOP PHOTOGRAPH: Humboldt River near Argenta, Nev., under no-flow conditions, looking west, October 1992. Photograph by Douglas K. Maurer, U.S. Geological Survey.

BACK COVER BOTTOM PHOTOGRAPH: Aerial view of Humboldt River at Battle Mountain, Nev., gaging station under flood conditions, looking north, March 1993. Photograph by R. Nyle Pennington, U.S. Geological Survey. 


\title{
Simulation of Streamflow, Middle Humboldt River, North-Central Nevada
}

\author{
By Glen W. Hess
}

Water-Resources Investigations Report 01-4231

Prepared in cooperation with the

NEVADA DIVISION OF WATER RESOURCES 


\title{
U.S. DEPARTMENT OF THE INTERIOR GALE A. NORTON, Secretary
}

\author{
U.S. GEOLOGICAL SURVEY \\ CHARLES G. GROAT, Director
}

Any use of trade, product, or firm names in this publication is for descriptive purposes only and does not imply endorsement by the U.S. Government

For additional information contact:

District Chief

U.S. Geological Survey 333 West Nye Lane, Room 203

Carson City, NV 89706-0866

email: usgsinfo_nv@usgs.gov

http://nevada.usgs.gov
Copies of this report can be purchased from:

U.S. Geological Survey Information Services

Building 810

Box 25286, Federal Center

Denver, CO 80225-0286 


\section{CONTENTS}

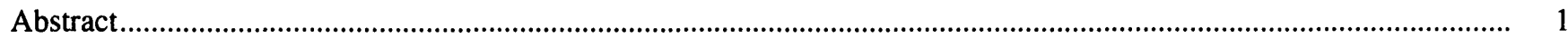

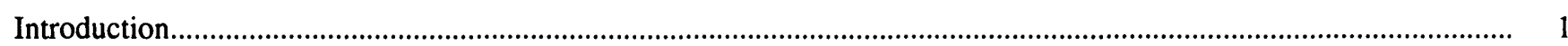

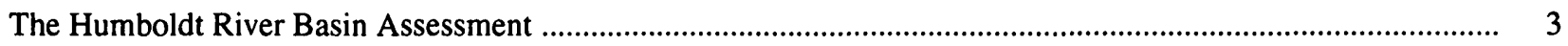

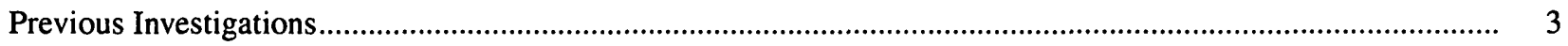

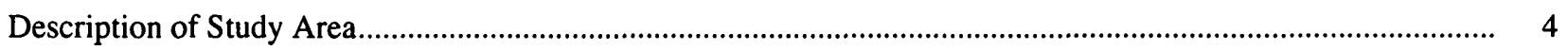

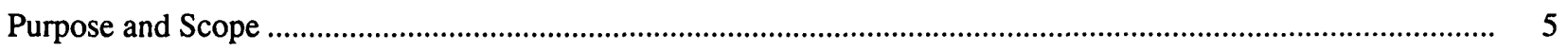

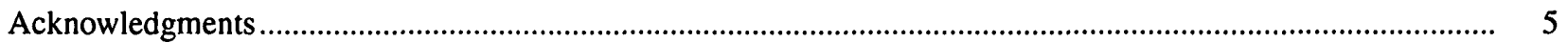

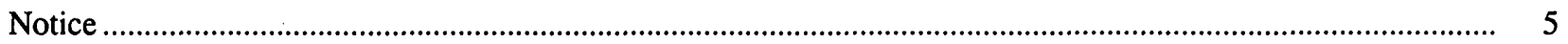

Description of Middle Humboldt River Operational Practices ...............................................................................

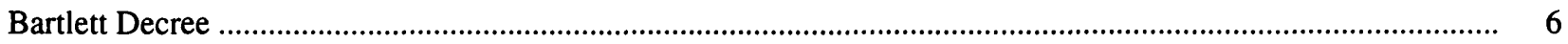

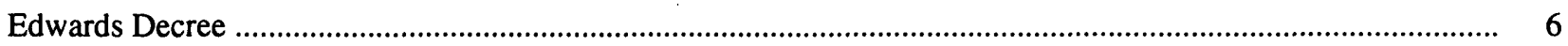

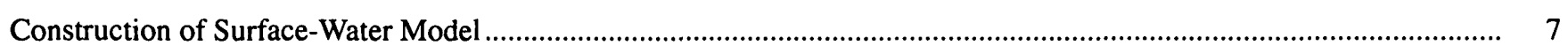

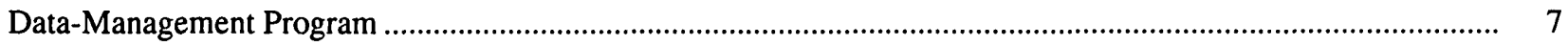

Hydrological Simulation Program-FORTRAN ...................................................................................... 8

Flow-Routing Module Used in Middle Humboldt River Model .................................................................. 9

Division of River into Reaches ......................................................................................................... 9

Hydraulic Characteristics of Reaches ................................................................................................... 9

Data Needed to Construct the Flow-Routing Module ........................................................................... 9

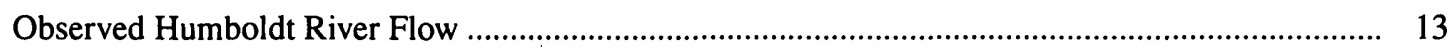

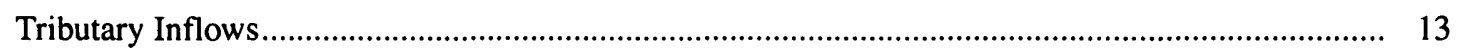

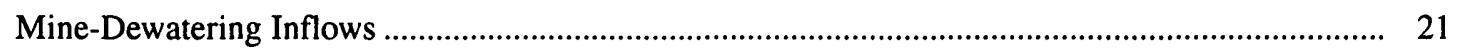

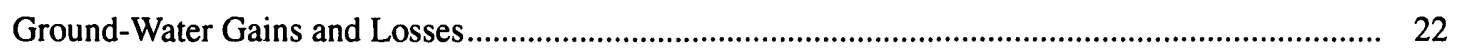

Assumptions Made to Simulate Streamflow Using Flow-Routing Module ............................................... 22

Operations Module Used in Middle Humboldt River Model .......................................................................... 22

Data and Logic Needed to Construct the Operations Module ............................................................ 22

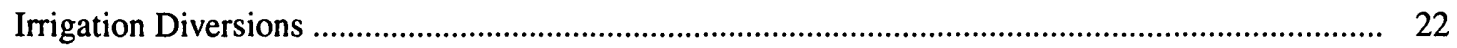

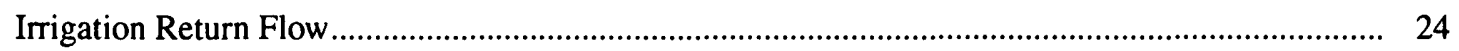

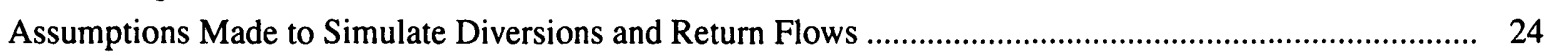

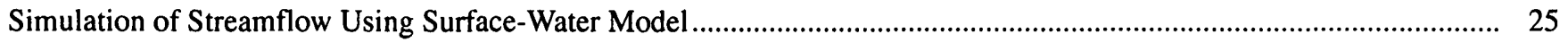

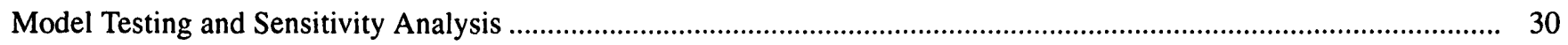

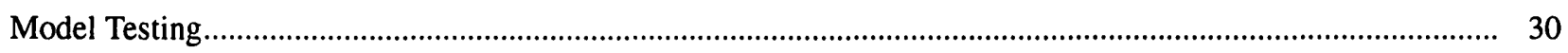

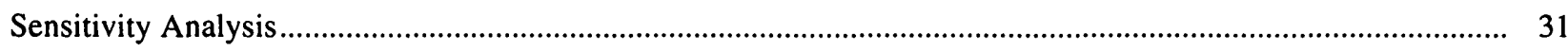

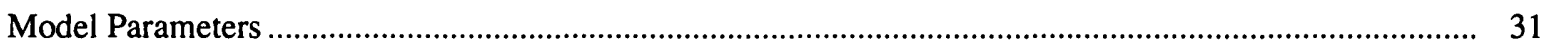

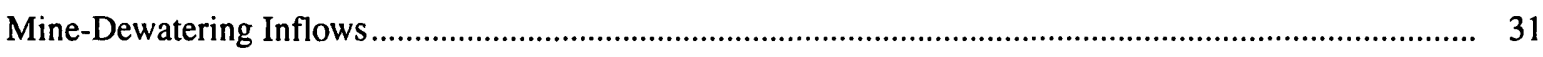

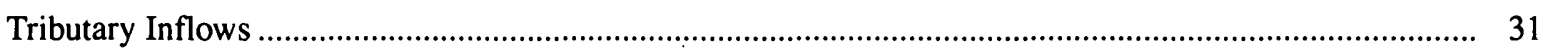

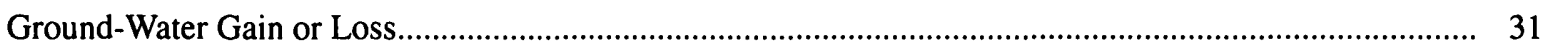

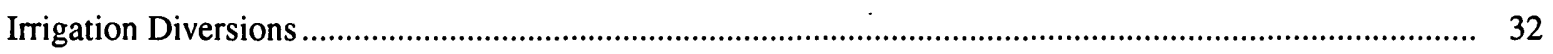

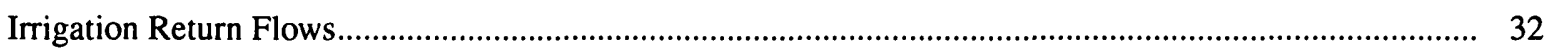

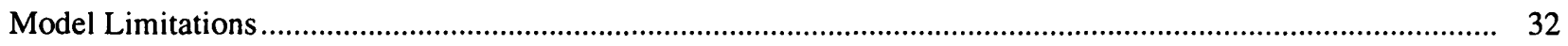

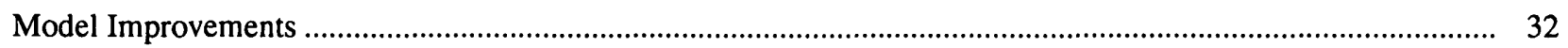

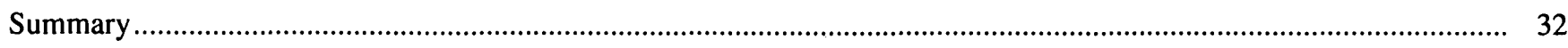

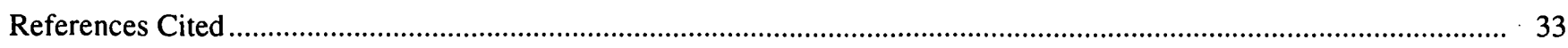

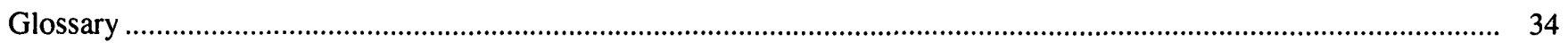


PLATE

Map showing hydrologic features, middle Humboldt River Basin, north-central Nevada (in pocket at back).

\section{FIGURES}

1. Map showing location and features of the study area and the Humboldt River Basin,

north-central Nevada

2. Flowchart showing relation of data management, and flow-routing and operations modules to middle Humboldt River model

3. Map showing location of selected streamflow gaging stations in north-central Nevada

4. Graph showing relation of streamflow diverted at White House Ditch in the 1985 irrigation season to concurrent flow of the Humboldt River at Palisade, Nevada.

5. Hydrographs showing observed and simulated monthly mean streamflow, wet conditions, water year 1998:

A. Humboldt River at Palisade

B. Humboldt River at Battle Mountain

C. Humboldt River near Comus

6. Hydrographs showing observed and simulated monthly mean streamflow, average conditions, water year 1964:
A. Humboldt River at Palisade
B. Humboldt River at Battle Mountain
C. Humboldt River near Comus

7. Hydrographs showing observed and simulated monthly mean streamflow, dry conditions, water year 1977:
A. Humboldt River at Palisade
B. Humboldt River at Battle Mountain
C. Humboldt River near Comus

8. Hydrographs showing typical conditions for observed and simulated monthly mean streamflow, water years 1951 and 1952:
A. Humboldt River at Palisade
B. Humboldt River at Battle Mountain
C. Humboldt River near Comus

\section{TABLES}

1. Name, size, and description of files managed by the ANNIE program for the middle Humboldt River model ... 6

2. Middle Humboldt River model reach inflows and outflows ............................................................................ 10

3. Selected reach characteristics of the middle Humboldt River used to describe hydraulic properties .................. 13

4. Streamflow gaging stations in the middle Humboldt River Basin data network used in the flow-routing and river-operations modules

5. Selected basin characteristics of tributaries to the middle Humboldt River used in the flow-routing and operations modules

6. Monthly streamflow duration characteristics of selected streams in northern Nevada.................................... 15

7. Streams in northern Nevada used to estimate tributary inflow to the middle Humboldt River ........................... 16

8. Selected basin physical and climatic characteristics of gaged tributary streams in north-central Nevada ........... 19

9. Regression equations used to determine monthly tributary inflow in the middle Humboldt River for use when gaging-station data are unavailable

10. Mine-dewatering inflows to the middle Humboldt River used in the flow-routing and operations modules....... 22

11. Estimates of ground-water gain or loss, by reach, used in the middle Humboldt River model .......................... 23

12. Relation of simulated monthly mean streamflow at Palisade, Battle Mountain, and Comus stream-gaging stations to changes in components of flow-routing and operations modules 
CONVERSION FACTORS AND VERTICAL DATUM

\begin{tabular}{rcl}
\hline Multiply & By & To obtain \\
\hline foot $(\mathrm{ft})$ & 0.3048 & meter \\
inch (in.) & 25.4 & millimeter \\
mile (mi) & 1.609 & kilometer \\
square mile $\left(\mathrm{mi}^{2}\right)$ & 2.590 & square kilometer \\
acre & 4,047 & square meter \\
acre-feet (acre-ft) & 1,233 & cubic meters \\
cubic foot per second $\left(\mathrm{ft}^{3} / \mathrm{s}\right)$ & 0.02832 & cubic meter per second \\
\hline
\end{tabular}

Sea level: In this report, "sea level" refers to the National Geodetic Vertical Datum of 1929 (NGVD of 1929, formerly called "Sea-Level Datum of 1929"), which is derived from a general adjustment of the first-order leveling networks of the United States and Canada. 


\title{
Simulation of Streamflow, Middle Humboldt River, North-Central Nevada
}

\author{
By Glen W. Hess
}

\section{ABSTRACT}

The surface-water computer model described in this report simulates streamflow and diversions at monthly time intervals, using inflow data from water years 1944-99, on the main stem of the Humboldt River between Carlin and Preble, Nevada. The model combines ANNIE, a data-base management program, with the Hydrological Simulation Program-FORTRAN, which employs various modules to simulate river operations and a range of hydrologic processes.

The model was constructed using both a flow-routing module, which characterizes the movement of water into and through 12 reaches of the drainage network, and an operations module, which simulates regulation of water movement within and out of the drainage network. The flowrouting module uses characteristics derived from river hydraulic data to define these reaches and observed data such as Humboldt River inflow and mine-dewatering inflow. Tributary inflow and ground-water gains or losses are estimated using various techniques. Conditional logic for the operations module is derived from the Bartlett and Edwards Decrees, which adjudicate surface-water rights in the Humboldt River Basin downstream and upstream, respectively, of Palisade, Nevada. Along each section of the river, irrigation diversions and return flows are managed according to these decrees.

Testing of the model indicates that model parameters adequately characterize Humboldt River hydraulics. Differences between observed and simulated streamflows indicate that tributary inflows may be undersimulated. Sensitivity analysis indicates that tributary inflows, irrigation diver- sions, and ground-water gains or losses are significant components in the model but that hydraulic model parameters, model reach area and volume, mine dewatering, and irrigation return flows are not. Possible improvements include the addition of information describing various hydrologic components, and integration of the surfacewater model with a ground-water model.

\section{INTRODUCTION}

The Humboldt River Basin, which encompasses an area of about $16,900 \mathrm{mi}^{2}$, is the only major river basin in Nevada whose drainage area lies entirely within the State. The area is characterized by generally northward-trending mountain ranges separated by broad alluvial valleys, typical of the Basin and Range physiographic province in which it is located. The study area for this report is the middle Humboldt River Basin (fig. 1), which consists of 14 hydrographic areas ${ }^{1}$ that encompass nearly $7,470 \mathrm{mi}^{2}$. The middle basin includes large land areas irrigated for agriculture as well as most of the large mining operations in northern Nevada.

Precipitation supplies all of the water that flows in the Humboldt River Basin, thus variability in climate can have a significant impact on the area's hydrology. Because precipitation on valley floors is sparse, agricultural interests must depend either on ground water or surface water for irrigation of crops and meadows. Agriculture traditionally has accounted for most of the

\footnotetext{
${ }^{1}$ Formal hydrographic areas in Nevada were delineated systematically by the U.S. Geological Survey (USGS) and the Nevada Division of Water Resources (NDWR) in the late 1960's for scientific and administrative purposes (Cardinalli and others, 1968; Rush, 1968). The official hydrographic-area names, numbers, and geographic boundaries continue to be used in USGS scientific reports and NDWR administrative activities.
} 


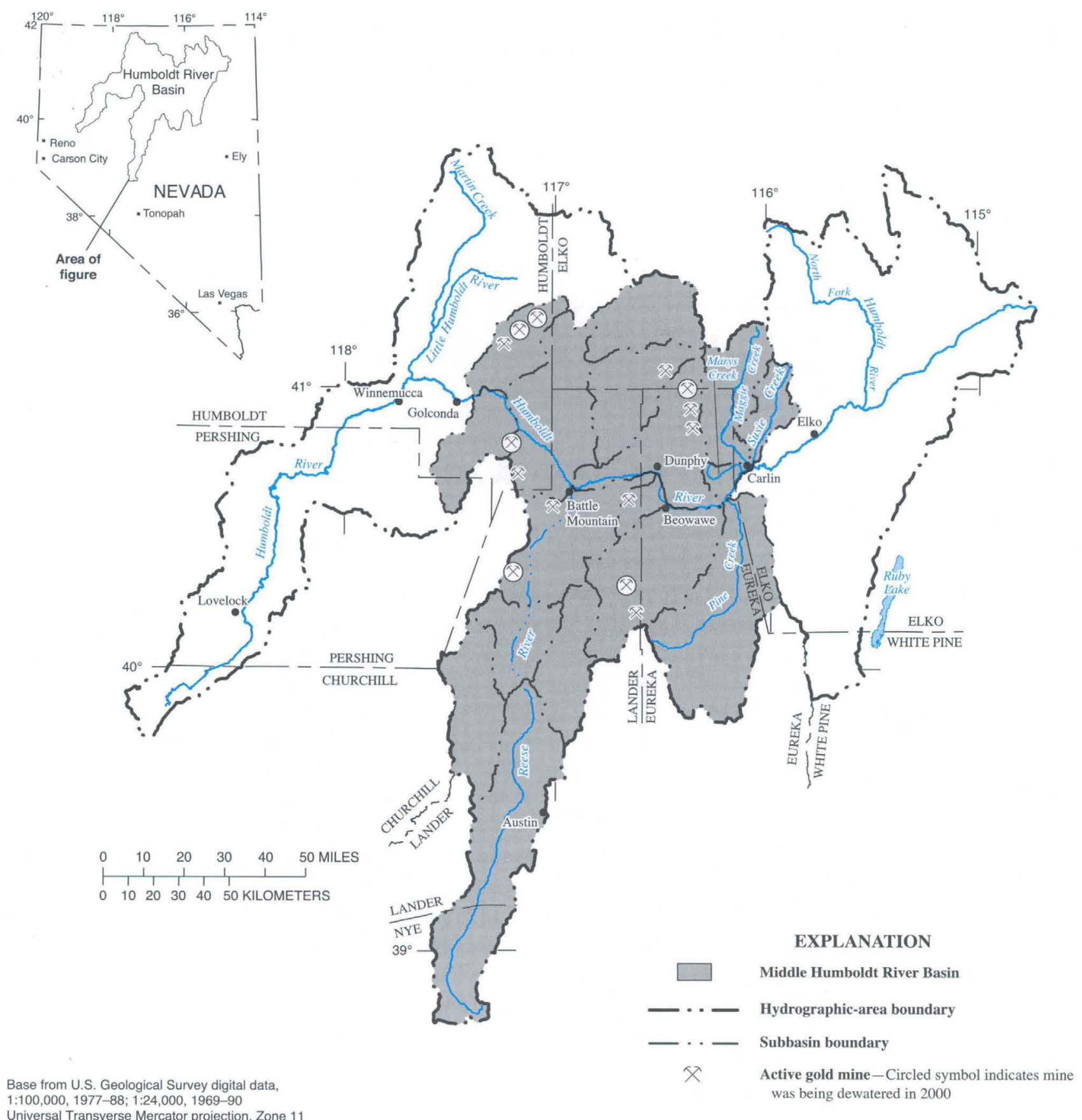

Figure 1. Location and features of the study area and the Humboldt River Basin, north-central Nevada. 
water use in the basin. In recent years, however, population increases have led to demands for more ground water for municipal and commercial supply. In addition, increased mining activities have placed additional demands on the basin's ground-water resources for both mining use and mine dewatering.

\section{The Humboldt River Basin Assessment}

Competing and at times incompatible demands for and uses of the scarce water resources of the Humboldt River Basin have raised concerns by State and local governments about the effects that these demands and uses have on the quantity and timing of streamflow on the main stem of the Humboldt River. Of particular concern are the regional and long-term effects of dewatering by open-pit mines. To address these concerns, the U.S. Geological Survey (USGS), in cooperation with the Nevada Department of Conservation and Natural Resources (NDCNR), has undertaken a comprehensive water-resources study of the basin called the Humboldt River Basin Assessment. The main objectives of the assessment are: (1) to provide a scientific appraisal of surface-water and ground-water resources of hydrographic areas within the Humboldt River Basin; (2) to determine the contribution of each area to the quantity and timing of flows in the main stem of the Humboldt River; and (3) to determine the effects of all major water users in the basin on the quantity, quality, and beneficial use of the basin's water resources.

Eakin and Lamke (1966, p. 17-18) divided the Humboldt River Basin (fig. 1) into upper, middle, and lower basins, and the Humboldt River Basin Assessment has continued to use these informal subdivisions. To date (2001), however, most assessment activities have focused on the middle Humboldt River Basin. This part of the basin includes: (1) large agricultural acreages that are irrigated both by surfacewater diversions and ground water; (2) 14 large gold mines, 8 of which are being dewatered and which discharge part of that water to the Humboldt River; and (3) the towns of Carlin, Crescent Valley, Beowawe, and Battle Mountain, which obtain their municipal water supplies by pumping ground water.

The assessment was planned as a series of phased studies. Phase one was begun in October 1994 and was completed in September 1998. Its main activities were to: (1) make hydrologic data collected by the USGS in the Humboldt River Basin available on the Internet at $<$ http://nevada.usgs.gov/humb>; (2) define the hydrogeologic framework of the basin in terms of aquifers that store and transmit ground water, confining units that impede ground-water movement, and groundwater conditions (Plume and Ponce, 1999); (3) develop and revise methods for estimating water budgets (Berger, 1999, 2000); and (4) quantify ground-water use (R.W. Plume, U.S. Geological Survey, written commun., 1998).

Phase two of the assessment, initiated in October 1998, will be completed in September 2004. Principal phase-two activities are to construct computer models of the ground-water and surface-water systems in the middle Humboldt River Basin. These two models will be linked so that the effects of climate change and human activities can be evaluated relative to both systems. The current study is part of phase 2 of the assessment.

\section{Previous Investigations}

In 1959, the Nevada State Legislature authorized the Humboldt River Research Project (Eakin and Lamke, 1966, p. 10). A Federal-State cooperative effort, the project's aims were to identify hydrologic data and information available for the basin, quantitatively describe hydrologic processes in the basin, and develop techniques needed to evaluate its water resources. To assess hydrologic conditions, investigators analyzed information dating from 1912 to 1963. In a reconnaissance-level evaluation of the Humboldt River Basin, Eakin and Lamke (1966) described various surface-water attributes, including runoff characteristics, flood-plain gradients, flow losses along the river, time of travel on the river, channel storage, and flood characteristics. They used synoptic streamflow measurements at sites along the river and tributaries to identify gaining and losing reaches of the streams, quantify parts of water budgets, and better understand relations of streams and aquifers.

Additionally, in 1960, the USGS began a cooperative study with the NDWR to provide preliminary appraisals of Nevada's water resources. These were published as a series of reconnaissance reports authorized by the Nevada State Legislature, and included an evaluation of the Humboldt River Valley near Winnemucca (Cohen and others, 1963) that analyzed surfacewater inflow, outflow, and streamflow characteristics in 
the study area. Synoptic measurements were made at sites along the river, at diversions, and at tributaries to determine streamflow gains and losses.

In 1988, in cooperation with the NDWR, the USGS began a study to define the water resources of the Maggie, Marys, and Susie Creek drainage basins and to characterize any effects of ground-water pumping at the Gold Quarry mine (Plume, 1995). This study defined flow characteristics for the three basins using streamflow records and synoptic measurements. A subsequent study (Maurer and others, 1996) documented hydrologic conditions in six basins along the Carlin trend, including surface-water characteristics of the Humboldt River and its tributaries.

During phase one of the Humboldt River Basin Assessment, Berger (1999) updated and refined methods used for estimating the different components of hydrographic-area water budgets. These methods included precipitation models based on precipitation from 1961 to 1990 , revised techniques for estimating mass-balance calculations, and new estimates of ground-water discharge. Berger (2000) used these methods to refine previously determined water budgets for 14 hydrographic areas in the middle Humboldt River Basin.

\section{Description of Study Area}

The Humboldt River originates in northeastern Nevada near Wells and flows to the west and southwest for a river distance of about $450 \mathrm{mi}$ to its termination in the Humboldt Sink near Lovelock (Warmath and Medina, 2001). This report focuses on two reaches of the river - one in the middle Humboldt River Basin and the other a short reach in the westernmost part of the upper Humboldt River Basin (pl. 1). For purposes of this report, the middle Humboldt River (fig. 1) is defined as that reach of the river that extends from the USGS stream-gaging station near Carlin (hereafter referred to as Carlin) to the State Route 789 bridge at Preble, which is about $5 \mathrm{mi}$ upstream from Golconda.

Horton (2000) reported the approximate floodplain length of the middle Humboldt River to be $87 \mathrm{mi}$, excluding the river's many meanders. The U.S. Army Corps of Engineers (1975, table 2) measured the same flood-plain length at $100.8 \mathrm{mi}$. For this study, using GIS methods, the river distance along the entire study area was determined to be about $154 \mathrm{mi}$. In addition, the river and flood-plain distances were compared between the gaging stations Humboldt River at Dunphy and Humboldt River at Battle Mountain (hereafter referred to as Dunphy and Battle Mountain, respectively). According to GIS methods, the river distance of this reach is $31 \mathrm{mi}$. The flood-plain distance, determined from aerial photographs taken on May 22, 1984, when the Humboldt River reached its third highest stage since 1907, was $24 \mathrm{mi}$. Together, these studies show the river channel length to be from 1.3 to 2.0 times the length of the flood plain.

The study area spans two climate zones: mid-latitude steppe and subhumid continental (Houghton and others, 1975, p. 3). The mid-latitude steppe zone, located at altitudes below $6,000 \mathrm{ft}$, has an arid climate with 6-7 in. annual precipitation as rain and snow. The subhumid continental zone, at higher altitudes, has about 25 in. annual precipitation, mostly as snow (Houghton and others, 1975, p. 71). Runoff entering the Humboldt River originates mostly as snowmelt from the slopes of nearby mountains, and, to a lesser extent, as runoff from rainfall.

The flow of the Humboldt River is generally westward through the study area (pl. 1). The average flow of the river at the Carlin gaging station is $385 \mathrm{ft}^{3} / \mathrm{s}$. Marys, Maggie, and Susie Creeks, which have a combined average flow of $49 \mathrm{ft}^{3} / \mathrm{s}$, enter the river at Carlin. Other sources of inflow include mine-dewatering flow from the Gold Quarry Mine that enters the Humboldt River via Maggie Creek. On a small unnamed tributary of Maggie Creek is Maggie Creek Dam and Reservoir, which has a capacity of 6,500 acre-ft and is used for temporary storage of excess water from the mine (pl. 1). In the valley downstream from Carlin, flood irrigation is used on pasture lands to support grazing. Below Tyrol, the river flows to the southwest and west through a canyon near Palisade where the average flow is 403 $\mathrm{ft}^{3} / \mathrm{s}$. Pine Creek, with an average flow of $13 \mathrm{ft}^{3} / \mathrm{s}$, is a perennial tributary that enters the river below Palisade.

Downstream from Beowawe, the Humboldt River flows to the northwest where the average valley-floor altitude is about $4,650 \mathrm{ft}$. The river flood plain adjacent to Whirlwind Valley is an agricultural area characterized by a complex system of channels, diversions, and return flows. The intricate canal-and-ditch system that begins above Beowawe and further downstream is used to irrigate fields in this area and farther downstream at Boulder Flat. The average flow of the Humboldt River 
at Dunphy is $454 \mathrm{ft}^{3} / \mathrm{s}$. The TS Ranch Dam and Reservoir, which is about $15 \mathrm{mi}$ north of Dunphy, is used for storage of excess water from the Betze Mine. Water from the reservoir was released to the Humboldt River by way of a canal for about 14 months in 1998-99. Since then, however, water from the reservoir has been used for irrigation in Boulder Flat. Willow Creek Reservoir, about 45 mi northeast of Battle Mountain, is on Willow Creek, a tributary of Rock Creek. The average flow of Rock Creek where it enters Boulder Flat is $41 \mathrm{ft}^{3} / \mathrm{s}$. Rock Creek flows to the southwest across Boulder Flat and enters the Humboldt River near Battle Mountain.

The average flow of the Humboldt River at Battle Mountain is $376 \mathrm{ft}^{3} / \mathrm{s}$. From here, the river flows to the northwest along a flood plain that is several miles wide. In this area, which has an average valley-floor altitude of about $4,400 \mathrm{ft}$, the primary agricultural activities are hay production and cattle grazing. Relict Humboldt River and Reese River channels formed by old meanders provide conduits for irrigation water during periods of overbank flow. The major relict channels in this area are the McIntyre and Herrin Sloughs (pl. 1).

Flowing to the northwest, the Humboldt River then enters the northern edge of Pumpernickel Valley near Red House Flat. Hay production and cattle grazing are in this area of the basin as well. Mine-dewatering inflows enter the Humboldt River from the south through the Lone Tree Mine cooling ponds and the Iron Point Relief Canal. Downstream from Red House Flat, where it has an average flow of $342 \mathrm{ft}^{3} / \mathrm{s}$, the river flows to the southwest through another agricultural area near Comus, then into a small canyon near Preble before flowing west toward Golconda and Winnemucca.

\section{Purpose and Scope}

This report discusses the development of a surface-water model of the middle Humboldt River, which is the reach of the river between the Carlin gaging station on the east and the bridge at Preble on the west (pl. 1). The report: (1) briefly describes operational practices in use on the middle Humboldt River; (2) documents construction of a model of monthly flows on the middle Humboldt River, including flow-routing and operations modules, data used to simulate flow routing and operations, operational logic, and simplifying assumptions; and (3) tests the hydrologic and hydraulic characterization of the middle Humboldt River model by comparing observed and simulated streamflow and by evaluating limitations of, and possible improvements to, the model. A monthly time step was chosen for model simulations because of the lack of complete data for all components of flows in this reach of the Humboldt River.

Streamflow and operations were simulated using streamflow data for water years 1944-99 (from October 1,1943 , to September 30, 1999). This period was chosen because streamflow data were collected at more gages during this time span than during previous periods. Moreover, this period represents a broad range of streamflows in the Humboldt River, allowing the accuracy of the model to be tested under conditions ranging from low flows during droughts to high flows during floods.

\section{Acknowledgments}

The author gratefully acknowledges the support of many people and agencies who provided data used in this report. NDWR water commissioners Steve Del Soldato and Wayne Testolin provided data used in this report. Del Soldato, Testolin, and State Engineer Hugh Ricci provided insight into the complexities and operation of the Humboldt River. Jim Brown, Chris Braley, and Nancy Fortune of Newmont Mining Corp. provided surveyed cross-sectional data along the river. Paul Pettit of Newmont Mining Corp. provided minedewatering flow data. Several ranch owners or managers permitted access to their lands along the river for purposes of measuring flows and surveying channel cross sections.

\section{Notice}

The customized software application and supporting materials (data and documentation) presented herein are made available by the USGS to be used in the public interest and for the advancement of science. Table 1 lists the model file names, sizes, description, and formats available. The authors, USGS, or the United States Government assume no liability for the contents or the use thereof. This documentation does not constitute a standard, specification, or regulation. 
Table 1. Name, size, and description of files managed by the ANNIE program for the middle Humboldt River model $^{1}$

\begin{tabular}{|c|c|c|}
\hline File name & Size (bytes) & Description \\
\hline hspf 12.0 & $5,859,268$ & $\begin{array}{l}\text { Binary file containing } \\
\text { source code for HSPF } \\
\text { model version } 12.0 \\
\text { (Bicknell and others, 1997). }\end{array}$ \\
\hline annie2.2 & $3,425,836$ & $\begin{array}{l}\text { Binary file containing } \\
\text { source code for data } \\
\text { management system } \\
\text { ANNIE (Lumb and others, } \\
\text { 1990). }\end{array}$ \\
\hline humb.wdm & $9,520,000$ & $\begin{array}{l}\text { Binary file created by } \\
\text { ANNIE which contains } \\
\text { data sets. }\end{array}$ \\
\hline humb.uci & 158,000 & $\begin{array}{l}\text { ASCIl-format file } \\
\text { containing user control } \\
\text { input file for operations } \\
\text { model. }\end{array}$ \\
\hline humtrib.uci & 161,000 & $\begin{array}{l}\text { ASCII-format file } \\
\text { containing user control } \\
\text { input file for computation } \\
\text { of Humboldt River tributary } \\
\text { inflows. }\end{array}$ \\
\hline
\end{tabular}

\footnotetext{
${ }^{1}$ For more information, contact Public Information Assistant by email at <GS-W-NVpublic-info@usgs.gov>. The model data base and source code are available both online and on a CD-ROM.
}

\section{DESCRIPTION OF MIDDLE HUMBOLDT RIVER OPERATIONAL PRACTICES}

Water rights in the Humboldt River Basin are based on the appropriative doctrine. Often expressed as "first in time, first in right," the doctrine states that the first person to put a quantity of water to beneficial use has a higher priority, or right, to the water than does a subsequent water user. Each water user is assigned a priority year (date of establishment of a water right) that is significant in relation to the dates assigned to other water users, particularly when available water is insufficient to meet all the needs of legal users. Under drought conditions, users with later appropriative dates may not receive the water allotted to them.

Because the Humboldt River Basin is entirely within the State of Nevada, water rights along the river have been determined solely through state decrees. Use and diversion of most of the flow of the Humboldt River are regulated by the Bartlett and Edwards Decrees (Hennen, 1964a; 1964b), which specify individual water rights. The Reese River system is subject to different decrees because its water does not normally discharge into the Humboldt River. NDWR water commissioners are responsible for administering distribution of water according to these decreed water rights.

Climatic conditions can vary greatly from year to year and between the upper and lower reaches of the Humboldt River. In wet years, Humboldt River streamflow can supply enough water for three irrigation cycles, while in dry years it may support only one cycle. Return flows from irrigation also can vary with climate. This variability is taken into consideration when the distribution of water is determined (Hennen, 1964b, p. 13-14).

\section{Bartlett Decree}

The 1931 Bartlett Decree (Mashburn and Mathews, 1943) adjudicates appropriative rights on the Humboldt River downstream of Palisade. The decree provides for a continuous flow rate of $0.81 \mathrm{ft}^{3} / \mathrm{s}$ for each 100 acres of water-righted lands. According to the decree, the irrigation season usually runs for six months from March 15 through September 15 of any given year (Mashburn and Mathews, 1943, p. 28-30). In practice, the dates of the irrigation season are determined by the amount of recent precipitation, the type of crop grown (harvest crop, meadow pasture, or diversified pasture), and the amount of water available in the river.

\section{Edwards Decree}

The 1935 Edwards Decree (Mashburn and Mathews, 1943) adjudicates appropriative rights on the Humboldt River upstream of Palisade. The decree provides for a continuous flow rate of $1.23 \mathrm{ft}^{3} / \mathrm{s}$ for each 100 acres of water-righted lands. According to the decree, the irrigation season usually runs for four months from April 15 through August 15 of any given year (Horton, 2000, p. I-70-71). As under the Bartlett Decree, the actual dates of the irrigation season are determined by the amount of recent precipitation, the type of crop grown, and the amount of water available in the river. 
Water distribution on the Humboldt River as defined by the two decrees forms the basis for the logic used in the operations module discussed in the following sections. This logic includes descriptions of irrigation diversions and irrigation return flows.

\section{CONSTRUCTION OF SURFACE-WATER MODEL}

To simulate monthly streamflow and river operations of the middle Humboldt River, a surface-water model (fig. 2) was constructed within a larger modeling system that includes ANNIE, a data-base management program (Lumb and others, 1990), and HSPF (Hydrological Simulation Program-FORTRAN), which simulates river operations and a variety of hydrologic processes (Bicknell and others, 1997). This modeling system provides standard formats for data exchange as well as support for statistical and graphical analysis (Bohman and others, 1995). Figure 2 shows how data management, flow-routing and operations modules, and hydraulic parameters are related to the middle Humboldt River model.
Surface-water models are unique applications of generic programs such as HSPF. Once data and parameters pertaining to a particular river or basin are input to the program, the resulting model cannot be used to simulate a different river or basin. ANNIE, HSPF, and the data from this study are available in electronic form.

\section{Data-Management Program}

Data used by the model are managed by ANNIE, an interactive program that combines file creation with data management, analysis, and display. ANNIE is used to manage the daily time-series data describing each component of the hydrologic system along the middle Humboldt River. Individual HSPF modules use the ANNIE time-series data as input and are capable of writing files as output to be formatted and managed by ANNIE. Each time-series of data is assigned a unique data set number and stored in the Watershed Data Management (WDM) file. Table 1 lists the model file names, sizes, descriptions, and available formats.

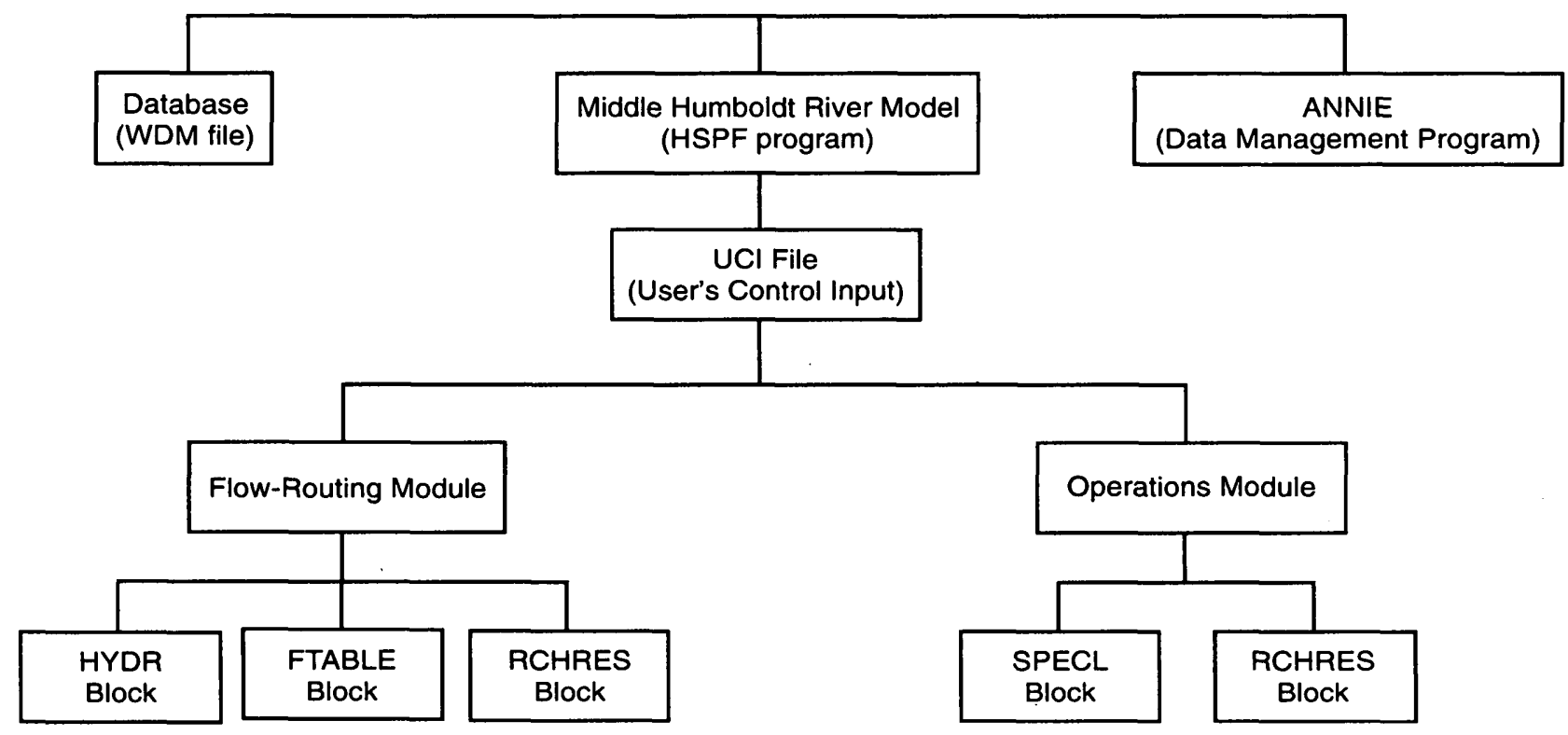

Figure 2. Flowchart showing relation of data management, and flow-routing and operations modules to middle Humboldt River model. 


\section{Hydrological Simulation Program-FORTRAN}

HSPF consists of a variety of modules used to simulate operations or physical hydrologic processes such as flow routing and precipitation-runoff, as well as associated water-quality processes on the land surface, in streams, and in well-mixed impoundments (Bicknell and others, 1997). Some of these HSPF modules can be used by themselves, while others must be used in combination with one or more other modules. The surface-water model for the middle Humboldt River requires the use of both a flow-routing module and an operations module. The flow-routing module characterizes the movement of water into and through each of the 12 reaches of the mainstem middle Humboldt River while the operations module simulates the regulation of water movement within and out of each reach. The two modules must be run in combination.

HSPF was chosen for use in this model primarily because it can: (1) simulate streamflows continuously over different flow regimes, including periods of storm runoff and low flows; (2) depict flow at a variety of time intervals, including monthly (this study), daily, and hourly; (3) incorporate the hydraulics of complex natural and constructed drainage networks; (4) account both for channel inflows and diversions along a stream reach; and (5) produce simulation results at each reach in the model.

The information the user must provide to run HSPF is in the user's control input (UCI) file, which controls simulation of specific physical processes. The UCI provides instructions to HSPF by defining where a module's input and output commands are stored. Instructions for additional modules describing physical processes may be added to the UCI; these modules then are called by the UCI in a logical stepwise fashion.

Each module in HSPF includes one or more "blocks" that group the computations needed by each module. The flow-routing module uses three blocks: (1) the unsteady-flow block (HYDR); (2) the reachproperties block (FTABLE); and (3) the reach-reservoir block (RCHRES). The operations module uses: (1) the RCHRES block; and (2) the special-actions block (SPECL). SPECL contains the conditional logic that simulates river operations. Both modules and all four blocks are required to fully simulate operations using HSPF.

The HYDR block is capable of simulating flow through a complex network of channels, reservoirs, and irrigation diversions and returns. HYDR represents physical processes of flow by treating river reaches as a series of linked (but not necessarily linear) reservoirs. (A reach is a single zone between two points along a river.) Inflow to and outflow from a reach either may be simulated by HSPF or provided to HSPF as actual timeseries data, such as streamflow measured at gaging stations. The outflow from one reach then is routed to the next downstream reach using a modified kinematicwave or storage-routing algorithm. Any water-conveyance system with known and unchanging hydraulic characteristics may be included in the flow network. Such systems include all streams, tributaries, lakes, and reservoirs as well as irrigation canals, ditches, and drains where open channel conditions occur.

The RCHRES block in HSPF simulates flow processes within a single reach. Flow through a reach is assumed to travel downstream only. Main-stem flow and additional sources, such as tributary and irrigation return flow, enter a reach from defined inlets. Precipitation, evaporation, evapotranspiration (ET), and other fluxes may affect the flow within a reach. Outflow in the model, such as irrigation diversions or groundwater losses, may leave a reach through a total of five defined outlets. RCHRES routes the streamflow by performing a water-budget analysis that accounts for all inflow to, outflow from, and volume of water stored in each reach for a given time interval.

In the FTABLE block, HSPF stores cross-sectional data or channel geometry representing hydraulic properties of a river reach. Information in the FTABLE block specifies a fixed relationship between depth, surface area, volume, and discharge for each river reach.

In summary, inflow and outflow data for the flowrouting module determine the volume of streamflow simulated by the model in RCHRES, whereas reach length and hydraulic characteristics in FTABLE determine the timing and effect of flows and how that volume is routed from an upstream to a downstream reach in HYDR.

To simulate river diversion operations, HSPF uses conditional logic derived from decrees such as the Bartlett and Edwards Decrees. Conditions that can be evaluated include time of year, reservoir stage, and storage; streamflow magnitude at a given location; and fulfillment of water demands or water rights. HSPF evaluates these conditions in reach (RCHRES) and simulates resultant operations. In the SPECL block, conditional logic controls inflows to and outflows from any particular river reach, which is required for each operations simulation. 


\section{Flow-Routing Module Used in Middle Humboldt River Model}

Specific information needed to develop and apply the flow-routing module included: (1) division of the river into reaches, (2) the hydraulic characteristics of each reach, (3) the data needed to construct the flowrouting module, and (4) the assumptions made for simulating streamflow. Each of these four items is discussed in detail in the following sections.

\section{Division of River into Reaches}

Boundaries for the 12 reaches of the middle Humboldt River were chosen primarily where the hydraulic characteristics change the magnitude of flow. The boundaries were based on changes in channel gradient, tributary inflow, diversion points, diversion returns, and locations of gaging stations (table 2). Reaches range in length from 2 to nearly $33 \mathrm{mi}$ (table 3 ). It is important to note that reach length is not measured as the linear distance between the ends of a reach. Instead, it is measured as the actual river channel distance, which as noted in a previous section can be as much as twice the linear distance. Humboldt River inflows and outflows for each reach are listed in table 2.

\section{Hydraulic Characteristics of Reaches}

Implementation of the HSPF flow-routing module requires detailed description of the hydraulic characteristics of the connected reaches of the stream being simulated. A representative set of hydraulic data must depict the cross-sectional features at several sites within each reach. The cross sections should be the most representative of the relation between stage and volume for that reach. Also required are channel length and average channel slope from each reach (table 3). The Channel Geometry Analysis Program (CGAP) (Regan and Schaffranek, 1985) uses these hydraulic data and the Manning equation to compute cross-sectional hydraulic features such as the area, volume, and discharge of each reach, and provides graphical representations of stage-discharge relations and cross-sectional plots. Plots allow visual checking of the data for errors in input. HSPF stores these cross-sectional data and channel geometry in tabular form in FTABLE for direct input to the HSPF model.
The hydraulic characteristics (cross-sectional area, length, and slope) of the 12 reaches used for the middle Humboldt River model were compiled from various sources. Newmont Mining Corporation and USGS surveyed 51 cross sections. Reach length (table 3) was determined from geographic information system (GIS) coverages by digitizing the June 1994 mainstem Humboldt River channel from digital orthophoto quadrangles (Warmath and Medina, 2001). The average slope of each reach (table 3 ) was determined from the change in altitude between cross sections and the distance along the river channel between sections. Reach length, in the form of river miles, is accessible on the Internet at <http://nevada.usgs.gov/humb>.

The accuracy of each surveyed cross section is believed to be $\pm 0.5 \mathrm{ft}$. The number of surveyed cross sections for individual reaches ranged from two for reach 3 to six for reach 6 . Field surveys included measuring the channel cross section up to the approximate altitude of the highest flood, estimating roughness coefficients, and describing auxiliary channels. Surveyed cross sections generally were at representative locations about every $3 \mathrm{mi}$ along the Humboldt River channel. In areas in which long overbank sections occurred, supplemental altitudes were determined from topographic maps in order to extend surveyed parts of cross sections so that each section would represent the full width of the flood plain.

\section{Data Needed to Construct the Flow-Routing Module}

Simulation of middle Humboldt River streamflow requires time series of hydrologic data describing river inflows and outflows. The data needed to simulate flows and test the flow-routing module are: (1) observed Humboldt River flow at the upstream model boundary, (2) tributary inflow data, (3) mine-dewatering inflow, and (4) ground-water gains or losses. The flow data were compiled into a comprehensive ANNIE data base in which each time series of data was assigned a unique data set number. Irrigation diversions and return flows are accounted for in a later section as part of the operations module. 
Table 2. Middle Humboldt River model reach inflows and outflows

\begin{tabular}{|c|c|c|c|c|}
\hline Reach & Inflow or outflow & Description & Type of data & Name \\
\hline \multirow[t]{9}{*}{1} & Inflow & Inflow to reach 1 & Measured & Humboldt River near Carlin \\
\hline & Inflow & Tributary inflow & Measured/estimated & Susie Creek at Carlin \\
\hline & Inflow & Mine dewatering inflow & Measured & Gold Quarry Mine discharge to Maggie Creek ${ }^{1}$ \\
\hline & Inflow & Tributary inflow & Measured/estimated & Maggie Creek at Carlin \\
\hline & Inflow & Tributary inflow & Measured/estimated & Marys Creek at Carlin \\
\hline & Outflow & Diversion & Simulated & Linebarger Ditch \\
\hline & Inflow & Return from diversion & Simulated & Linebarger Ditch return \\
\hline & Inflow/outflow & Ground water gain or loss & Estimated & \\
\hline & Outflow & Outflow from reach 2 & Simulated & Humboldt River below Carlin \\
\hline \multirow[t]{8}{*}{2} & Inflow & Inflow from reach 1 & Simulated & \\
\hline & Inflow & Tributary inflow & Estimated & Woodruff Creek \\
\hline & Outflow & Diversion & Simulated & Griffin Ditch \\
\hline & Inflow & Return from diversion & Simulated & Griffin Ditch return \\
\hline & Outflow & Diversion & Simulated & Palisade Ditch \\
\hline & Inflow & Return from diversion & Simulated & Palisade Ditch return \\
\hline & Inflow/outflow & Ground water gain or loss & Estimated & \\
\hline & Outflow & Outflow to reach 3 & Simulated & Humboldt River above Palisade \\
\hline \multirow[t]{3}{*}{3} & Inflow & Inflow from reach 2 & Simulated & \\
\hline & Inflow/outflow & Ground water gain or loss & Estimated & \\
\hline & Outflow & Outflow to reach 4 & Simulated & Humboldt River at Palisade \\
\hline \multirow[t]{6}{*}{4} & Inflow & Inflow from reach 3 & Simulated & \\
\hline & Inflow & Tributary inflow & Measured/estimated & Pine Creek near Palisade \\
\hline & Outflow & Diversion & Simulated & Harney Ditch \\
\hline & Inflow & Return from diversion & Simulated & Harney Ditch return \\
\hline & Inflow/outflow & Ground water gain or loss & Estimated & \\
\hline & Outflow & Outflow to reach 5 & Simulated & Humboldt River below Harney \\
\hline \multirow[t]{6}{*}{5} & Inflow & Inflow from reach 4 & Simulated & \\
\hline & Outflow & Diversion & Simulated & Highline Canal \\
\hline & Outflow & Diversion & Simulated & Corbett Canal \\
\hline & Inflow & Tributary inflow & Estimated & Crescent and Whirlwind Valleys \\
\hline & Inflow/outflow & Ground water gain or loss & Estimated & \\
\hline & Outflow & Outflow to reach 6 & Simulated & Humboldt River at Beowawe \\
\hline
\end{tabular}


Table 2. Middle Humboldt River model reach inflows and outflows-Continued

\begin{tabular}{|c|c|c|c|c|}
\hline Reach & Inflow or outflow & Description & Type of data & Name \\
\hline \multirow[t]{13}{*}{6} & Inflow & Inflow from reach 5 & Simulated & \\
\hline & Inflow & Return from diversion & Simulated & Highline Canal return \\
\hline & Inflow & Return from diversion & Simulated & Corbett Canal return \\
\hline & Outflow & Diversion & Simulated & Merchant Canal \\
\hline & Inflow & Return from diversion & Simulated & Merchant Canal return \\
\hline & Outflow & Diversion & Simulated & Westside Ditch \\
\hline & Inflow & Return from diversion & Simulated & Westside Ditch return \\
\hline & Outflow & Diversion & Simulated & White House Ditch \\
\hline & Inflow & Return from diversion & Simulated & White House Ditch return \\
\hline & Outflow & Diversion & Simulated & Rose Canal \\
\hline & Inflow & Return from diversion & Simulated & Rose Canal return \\
\hline & Inflow/outflow & Ground water gain or loss & Estimated & . \\
\hline & Outflow & Outflow to reach 7 & Simulated & Humboldt River at old US 40 at Dunphy \\
\hline \multirow[t]{8}{*}{7} & Inflow & Inflow from reach 6 & Simulated & \\
\hline & Inflow & Mine dewatering inflow & Measured & Betze Mine ${ }^{l}$ \\
\hline & Outflow & Diversion & Simulated & Blue House Ditch \\
\hline & Inflow & Return from diversion & Simulated & Blue House Ditch return \\
\hline & Outflow & Diversion & Simulated & Slaven Ditch \\
\hline & Inflow & Return from diversion & Simulated & Slaven Ditch return \\
\hline & Inflow/outflow & Ground water gain or loss & Estimated & \\
\hline & Outflow & Outflow to reach 8 & Simulated & Humboldt River near Argenta \\
\hline \multirow[t]{11}{*}{8} & Inflow & Inflow from reach 7 & Simulated & \\
\hline & Inflow & Tributary inflow & Measured/estimated & Boulder Creek \\
\hline & Outflow & Diversion & Estimated & Tomera Ditch \\
\hline & Inflow & Return from diversion & Simulated & Tomera Ditch return \\
\hline & Outflow & Diversion & Simulated & Erickson Ditch \\
\hline & Inflow & Return from diversion & Simulated & Erickson Ditch return \\
\hline & Outflow & Diversion & Simulated & Licking Ditch \\
\hline & Inflow & Return from diversion & Simulated & Licking Ditch return \\
\hline & Inflow & Tributary inflow & Measured/estimated & Rock Creek near Battle Mountain \\
\hline & Inflow/outflow & Ground water gain or loss & Estimated & \\
\hline & Outflow & Outflow to reach 9 & Simulated & Humboldt River at Battle Mountain \\
\hline
\end{tabular}


Table 2. Middle Humboldt River model reach inflows and outflows-Continued

\begin{tabular}{|c|c|c|c|c|}
\hline Reach & Inflow or outflow & Description & Type of data & Name \\
\hline \multirow[t]{8}{*}{9} & Inflow & Inflow from reach 8 & Simulated & \\
\hline & Outflow & Diversion & Simulated & 26 Ranch Ditch \\
\hline & Inflow & Return from diversion & Simulated & 26 Ranch Ditch return \\
\hline & Inflow & Tributary inflow & Estimated & Reese River \\
\hline & Outflow & Diversion & Simulated & DL Ranch Ditch \\
\hline & Inflow & Return from diversion & Simulated & DL Ranch Ditch return \\
\hline & Inflow/outflow & Ground water gain or loss & Estimated & \\
\hline & Outflow & Outflow to reach 10 & Simulated & Humboldt River near Valmy \\
\hline \multirow[t]{5}{*}{10} & Inflow & Inflow from reach 9 & Simulated & \\
\hline & Outflow & Diversion & Simulated & Ellison Ditch \\
\hline & Inflow & Return from diversion & Simulated & Ellison Ditch return \\
\hline & Inflow/outflow & Ground water gain or loss & Estimated & \\
\hline & Outflow & Outflow to reach 11 & Simulated & Humboldt River near Valmy \\
\hline \multirow[t]{12}{*}{11} & Inflow & Inflow from reach 10 & Simulated & \\
\hline & Inflow & Tributary inflow & Estimated & Pumpernickel Valley \\
\hline & Inflow & Tributary inflow & Estimated & Clovers Area \\
\hline & Inflow & Mine dewatering inflow & Measured & Lone Tree mine via Iron Point Relief Canal ${ }^{1}$ \\
\hline & Outflow & Diversion & Simulated & Red House Ditch \\
\hline & Inflow & Return from diversion & Simulated & Red House Ditch return \\
\hline & Outflow & Diversion & Simulated & Gonzales Ditch \\
\hline & Inflow & Return from diversion & Simulated & Gonzales Ditch return \\
\hline & Outflow & Diversion & Simulated & Bliss Ditch \\
\hline & Inflow & Return from diversion & Simulated & Bliss Ditch return \\
\hline & Inflow/outflow & Ground water gain or loss & Estimated & \\
\hline & Outflow & Outflow to reach 11 & Simulated & Humboldt River near Comus \\
\hline \multirow[t]{8}{*}{12} & Inflow & Inflow from reach 11 & Simulated & \\
\hline & Inflow & Tributary inflow & Estimated & Kelly Creek \\
\hline & Outflow & Diversion & Simulated & Christenson Ditch \\
\hline & Inflow & Return from diversion & Simulated & Christenson Ditch return \\
\hline & Outflow & Diversion & Simulated & Petit Ditch \\
\hline & Inflow & Return from diversion & Simulated & Petit Ditch return \\
\hline & Inflow/outflow & Ground water gain or loss & Estimated & \\
\hline & Outflow & & Simulated & Humboldt River at Preble \\
\hline
\end{tabular}

${ }^{1}$ See table 10 for period of record for mine dewatering. 
Table 3. Selected reach characteristics of the middle Humboldt River used to describe hydraulic properties

\begin{tabular}{ccc}
\hline $\begin{array}{c}\text { Reach number } \\
\text { (pl. 1) }\end{array}$ & $\begin{array}{c}\text { Reach length } \\
\text { (miles) }\end{array}$ & $\begin{array}{c}\text { Reach slope } \\
\text { (foot per foot) }\end{array}$ \\
\hline 1 & 10.76 & 0.00075 \\
2 & 6.96 & .00073 \\
3 & 2.00 & .00136 \\
4 & 9.03 & .00080 \\
5 & 12.03 & .00104 \\
6 & 14.62 & .00079 \\
7 & 17.13 & .00083 \\
8 & 14.29 & .00033 \\
9 & 32.70 & .00037 \\
10 & 4.16 & .00067 \\
11 & 20.65 & .00023 \\
12 & 9.48 & .00037 \\
\hline
\end{tabular}

\section{Observed Humboldt River Flow}

Streamflow data for water years 1944-99 at the Carlin gaging station were used as inflows at the upstream model boundary. Streamflow data for six Humboldt River gaging stations were used to test simulated streamflow at interior model points (pl. 1, table 4). These data were consolidated into the Humboldt River data base. However, the periods of record for these USGS gaging stations differ and generally do not include the entire 1944-99 period (table 4).

\section{Tributary Inflows}

The simulation of middle Humboldt River streamflow for the 1944-99 period is dependent either on measured or estimated tributary inflows to the river. Because tributary inflows were not regularly measured during the 1944-99 period, a method was developed to estimate the inflows when gaging-station data are unavailable. Techniques from previous investigators and statistical analysis of flow data from gaged basins in central and northern Nevada were used to make the estimates of tributary inflows. These estimated inflows then were distributed to the model river reaches. The following sections list major middle Humboldt River tributaries, previous flow estimation techniques, and the methods used in this study to estimate tributary inflows to the middle Humboldt River.

The middle Humboldt River receives varying amounts of inflow from 12 principal tributaries (see table 5 and pl. 1 for site locations). Mashburn and Mathews (1943, p. 23-26) recognized these and other Humboldt River tributaries and defined the general timing of runoff from them. Eakin and Lamke (1966, p. 36) estimated average annual runoff for Humboldt River tributaries at their respective mouths. On the basis of these two studies and on observations made during the current study, five of the tributaries (Crescent and Whirlwind Valleys, Boulder Flat, Clovers Area; Pumpernickel Valley, and the Kelley Creek area) were determined to be non-contributing, with minimal inflow to the Humboldt River. The seven tributaries

Table 4. Streamflow gaging stations in the middle Humboldt River Basin data network used in the flow-routing and river-operations modules

\begin{tabular}{ccllr}
\hline $\begin{array}{c}\text { Site number } \\
\text { (pl. 1) }\end{array}$ & $\begin{array}{c}\text { Station } \\
\text { number }\end{array}$ & \multicolumn{1}{c}{ Station name } & \multicolumn{1}{c}{$\begin{array}{c}\text { Period of record } \\
\text { (water year) }\end{array}$} & $\begin{array}{c}\text { ANNIE data- } \\
\text { set number }\end{array}$ \\
\hline 2 & 10321000 & Humboldt River near Carlin & $1944-99$ & 210 \\
4 & 10322500 & Humboldt River at Palisade & $1903-06,1911-99$ & 250 \\
5 & 10323425 & $\begin{array}{c}\text { Humboldt River at old U.S. Highway 40 } \\
\text { bridge, at Dunphy }\end{array}$ & $1991-99$ & 270 \\
7 & 10323500 & Humboldt River near Argenta & $1946-83$ & 280 \\
9 & 10325000 & Humboldt River at Battle Mountain & $1921-24,1946-81,1991-99$ & 300 \\
10 & 10327000 & Humboldt River near Valmy & $1950-58$ & 315 \\
12 & 10327500 & Humboldt River near Comus & $1895-1926,1946-99$ & 320 \\
\hline
\end{tabular}


Table 5. Selected basin characteristics of tributaries to the middle Humboldt River used in the flow-routing and operations modules

\begin{tabular}{|c|c|c|c|c|c|}
\hline Humboldt tributary basin & $\begin{array}{l}\text { Drainage } \\
\text { area }\left(\mathbf{m i}^{2}\right)\end{array}$ & $\begin{array}{c}\text { Latitude } \\
\text { (decimal degrees) }\end{array}$ & $\begin{array}{c}\text { Longitude } \\
\text { (decimal degrees) }\end{array}$ & $\begin{array}{l}\text { Model } \\
\text { reach }\end{array}$ & $\begin{array}{c}\text { ANNIE data-se } \\
\text { number }\end{array}$ \\
\hline Susie Creek & 194 & 40.725 & 116.077 & 1 & 9800 \\
\hline Maggie Creek & 400 & 40.716 & 116.092 & 1 & 9801 \\
\hline Marys Creek & 45.4 & 40.711 & 116.125 & 1 & 9802 \\
\hline Woodruff Creek & 60.6 & 40.700 & 116.13 & 2 & 9803 \\
\hline Pine Creek & 999 & 40.595 & 116.174 & 4 & 9804 \\
\hline Crescent and Whirlwind Valleys ${ }^{1}$ & 1,130 & 40.66 & 116.40 & 5 & 9805 \\
\hline Boulder Flat ${ }^{1}$ & 540 & 40.650 & 116.67 & 8 & 9807 \\
\hline Rock Creek & 875 & 40.824 & 116.584 & 8 & 9806 \\
\hline Reese River & 2,510 & 40.667 & 116.993 & 9 & 9808 \\
\hline Clovers Area ${ }^{1}$ & 300 & 40.92 & 116.00 & 11 & 9810 \\
\hline Pumpernickel Valley ${ }^{1}$ & 300 & 40.83 & 116.00 & 11 & 9809 \\
\hline Kelley Creek ${ }^{1}$ & 300 & 41.00 & 117.33 & 12 & 9811 \\
\hline
\end{tabular}

${ }^{1}$ Flow is minimal from this basin or stream to the Humboldt River.

that do flow into the middle Humboldt River are, in downstream order: Susie Creek, Maggie Creek, Marys Creek, Woodruff Creek, Pine Creek, Rock Creek, and the Reese River.

Flows of ungaged streams or of stream gaging stations with incomplete records can be estimated using two different methods. The "index method," described by Maurer (1986, p. 13-15) determined regression equations to estimate streamflow at seven tributaries to the Carson River in western Nevada and eastern California. His estimates were based on streamflow records for an index gaging station and on concurrent discharge measurements at the ungaged streams. Hess (1999, p. 4-9) updated the equations with additional concurrent discharge measurements and extended the estimates to include four additional tributaries to the upper Carson River.

The "duration method," described by Parrett and Cartier (1990), used methods applicable to western Montana basins for estimating mean monthly discharge and various points on the daily mean-flow duration curve for each month. One method was based on multiple regression equations relating the monthly streamflow characteristics to various basin and climatic variables. Hess and Bohman (1996) developed techniques for estimating monthly mean streamflow and monthly streamflow duration characteristics in central Nevada using streamflow data at gaged sites. A streamflow-duration curve is a cumulative frequency curve that shows the percentage of time that specified discharges are equalled or exceeded.

For the middle Humboldt River, regression analysis was not used to directly estimate unique, historical (1944-99) streamflows of the seven tributaries listed in table 5. Instead, the duration method was used to develop an estimated streamflow-duration curve for each of the seven tributaries. This was done by relating streamflow-duration curves for three index gaging stations in the Humboldt River Basin to estimated streamflow-duration curves determined from regression equations similar to those in Parrett and Cartier (1990) and Hess and Bohman (1996). The regression equations were determined by relating streamflow characteristics of the duration curve at 31 gaged tributaries (tables 6 and 7) to its basin and climatic characteristics. Ten of these gaged tributaries are within the Humboldt River Basin and the rest are outside the basin in northern and central Nevada (fig. 3).

For this study, the USGS gaging stations at Lamoille Creek near Lamoille, Rock Creek near Battle Mountain, and Martin Creek near Paradise Valley were used as index stations for the seven tributaries listed in 
Table 6. Monthly streamflow duration characteristics of selected streams in northern Nevada

\begin{tabular}{|c|c|c|c|c|c|c|c|c|c|c|}
\hline \multirow{2}{*}{$\begin{array}{l}\text { Station } \\
\text { number }\end{array}$} & \multirow{2}{*}{ Station name } & \multicolumn{9}{|c|}{ Monthly streamflow equaled or exceeded for indicated percentage of time, in cubic feet per second } \\
\hline & & 1 & 5 & 10 & 25 & 50 & 75 & 90 & 95 & 99 \\
\hline 10243240 & Baker Creek at Narrows, near Baker & 122 & 41.2 & 23.0 & 8.05 & 2.86 & 1.95 & 1.44 & 0.79 & 0.20 \\
\hline 10243260 & Lehman Creek near Baker & 39.2 & 19.1 & 12.9 & 6.10 & 2.53 & 1.59 & 1.26 & 1.15 & .82 \\
\hline 10243700 & Cleve Creek near Ely & 66.8 & 28.3 & 19.5 & 11.0 & 7.74 & 6.00 & 5.03 & 4.56 & 3.99 \\
\hline 10244720 & Franklin River near Arthur & 77.9 & 51.0 & 38.7 & 11.1 & 3.33 & 2.17 & 1.63 & 1.48 & .97 \\
\hline 10244950 & Steptoe Creek near Ely & 31.8 & 20.5 & 13.3 & 7.79 & 4.73 & 3.60 & 2.76 & 2.41 & 1.97 \\
\hline 10245445 & Illipah Creek near Hamilton & 9.4 & 8.61 & 8.13 & 4.77 & 2.16 & .84 & .55 & .44 & .30 \\
\hline 10245800 & Newark Valley tributary near Hamilton & 21.4 & 9.95 & 4.57 & .44 & .09 & .02 & .01 & .01 & .01 \\
\hline 10245900 & Pine Creek near Belmont & 61.0 & 21.7 & 16.5 & 4.53 & 1.97 & 1.37 & 1.10 & 1.02 & .83 \\
\hline 10245910 & Mosquito Creek near Belmont & 17.3 & 9.36 & 4.57 & 1.71 & .78 & .49 & .33 & .27 & .16 \\
\hline 10245925 & Stoneberger Creek near Austin & 24.4 & 6.33 & 3.05 & 1.26 & .45 & .24 & .18 & .15 & .10 \\
\hline 10246846 & Little Currant Creek near Currant & 35.6 & 18.7 & 11.9 & 4.07 & 1.36 & .51 & .18 & .09 & .03 \\
\hline 10249190 & Willow Creek near Warm Springs & 61.0 & 21.7 & 16.5 & 4.53 & 1.97 & 1.37 & 1.10 & 1.02 & .83 \\
\hline 10249280 & Kingston Creek below Cougar Canyon near Austin & 36.9 & 9.61 & 4.57 & 1.76 & .82 & .49 & .33 & .25 & .16 \\
\hline 10249300 & South Twin River near Round Mountain & 57.5 & 25.5 & 3.05 & 6.38 & 2.90 & 1.99 & 1.49 & 1.25 & .92 \\
\hline 10249900 & Chiatovich Creek near Dyer & 32.4 & 17.3 & 13.7 & 9.52 & 7.45 & 6.24 & 5.15 & 4.46 & 3.27 \\
\hline 10315500 & Marys River above Hot Springs Creek near Deeth & 466 & 297 & 214 & 73.4 & 20.2 & 5.79 & 1.93 & 1.35 & .56 \\
\hline 10316500 & Lamoille Creek near Lamoille & 332 & 222 & 159 & 42.5 & 8.86 & 5.38 & 3.85 & 3.33 & 2.66 \\
\hline 10319500 & Huntington Creek near Lee & 360 & 162 & 98.1 & 35.8 & 12.6 & 5.94 & 3.03 & 2.26 & 1.44 \\
\hline 10320500 & South Fork Humboldt River near Elko & 946 & 556 & 382 & 158 & 38.4 & 15.5 & 5.85 & 2.81 & .35 \\
\hline 10323000 & Pine Creek near Palisade & 126 & 63.6 & 28.0 & 15.4 & 8.45 & 2.13 & .27 & .17 & .08 \\
\hline 10324500 & Rock Creek near Battle Mountain & 487 & 196 & 120 & 34.3 & 6.27 & 1.67 & .63 & .24 & .05 \\
\hline 10325500 & Reese River near Ione & 139 & 60.0 & 33.6 & 9.56 & 3.86 & 2.42 & 1.53 & 1.20 & .59 \\
\hline 10328000 & Pole Creek near Golconda & 27.4 & 17.9 & 13.7 & 4.98 & 1.71 & .55 & .22 & .12 & .03 \\
\hline 10329000 & Little Humboldt River near Paradise Valley & 201 & 86.5 & 63.3 & 25.3 & 9.98 & 7.20 & 6.47 & 6.20 & 5.65 \\
\hline 10329500 & Martin Creek near Paradise Valley & 242 & 142 & 99.7 & 41.4 & 11.1 & 7.31 & 5.75 & 5.20 & 4.29 \\
\hline 10353000 & East Fork Quinn River near McDermitt & 245 & 104 & 76.1 & 28.8 & 6.76 & 3.41 & 1.64 & 1.23 & .53 \\
\hline 10353700 & Leonard Creek near Denio & 36.2 & 18.1 & 13.7 & 6.89 & 3.83 & 2.42 & 1.64 & 1.37 & .65 \\
\hline 10353750 & Mahogany Creek near Summit Lake & 27.9 & 13.7 & 6.90 & 3.65 & 2.01 & 1.28 & .89 & .77 & .45 \\
\hline 10353770 & South Willow Creek near Gerlach & 13.6 & 8.34 & 4.59 & 1.28 & .28 & .07 & .02 & .01 & .01 \\
\hline 13161500 & Bruneau River at Rowland & 744 & 501 & 351 & 117 & 40.4 & 19.9 & 11.5 & 8.17 & 4.58 \\
\hline- & East Stewart Creek near Ione & 2.04 & 1.22 & .87 & .38 & .20 & .12 & .08 & .07 & .05 \\
\hline
\end{tabular}


Table 7. Streams in northern Nevada used to estimate tributary inflow to the middle Humboldt River

\begin{tabular}{|c|c|c|c|c|}
\hline $\begin{array}{l}\text { Site number } \\
\text { (fig. 3) }\end{array}$ & $\begin{array}{l}\text { Station } \\
\text { number }\end{array}$ & Station name & $\begin{array}{l}\text { Period of record } \\
\text { (water year) }\end{array}$ & $\begin{array}{l}\text { ANNIE data- } \\
\text { set number }\end{array}$ \\
\hline 1 & 10243240 & Baker Creek at Narrows, near Baker & $1948-55,1993-97$ & 10 \\
\hline 2 & 10243260 & Lehman Creek near Baker & $1948-55,1993-97$ & 20 \\
\hline 3 & 10243700 & Cleve Creek near Ely & $1914-99^{a}$ & 30 \\
\hline 4 & 10244720 & Franklin River near Arthur & $1964-83$ & 40 \\
\hline 5 & 10244950 & Steptoe Creek near Ely & $1966-99$ & 50 \\
\hline 6 & 10245445 & Illipah Creek near Hamilton & $1983-87,1990-94$ & 60 \\
\hline 7 & 10245800 & Newark Valley tributary near Hamilton & $1962-86$ & 70 \\
\hline 8 & 10245900 & Pine Creek near Belmont & 1978-99 & 80 \\
\hline 9 & 10245910 & Mosquito Creek near Belmont & 1978-99 & 90 \\
\hline 10 & 10245925 & Stoneberger Creek near Austin & 1978-97 & 100 \\
\hline 11 & 10246846 & Little Currant Creek near Currant & $1965-81,1983-86,1990-94$ & 110 \\
\hline 12 & 10249190 & Willow Creek near Warm Springs & 1978-92 & 120 \\
\hline 13 & 10249280 & Kingston Creek below Cougar Canyon near Austin & $1967-99$ & 130 \\
\hline 14 & 10249300 & South Twin River near Round Mountain & 1965-99 & 140 \\
\hline 15 & 10249900 & Chiatovich Creek near Dyer & $1961-82$ & 150 \\
\hline 16 & 10315500 & Marys River above Hot Springs Creek near Deeth & $1944-80,1982-99$ & 160 \\
\hline 17 & 10316500 & Lamoille Creek near Lamoille & $1915-23,1944-99$ & 170 \\
\hline 18 & 10319500 & Huntington Creek near Lee & 1949-72 & 190 \\
\hline 19 & 10320500 & South Fork Humboldt River near Elko & $1896-1973^{\mathrm{a}}$ & 200 \\
\hline 20 & 10323000 & Pine Creek near Palisade & $1912-14,1946-58$ & 260 \\
\hline 21 & 10324500 & Rock Creek near Battle Mountain & $1918-29,1946-99^{a}$ & 290 \\
\hline 22 & 10325500 & Reese River near Ione & $1951-80$ & 310 \\
\hline 23 & 10328000 & Pole Creek near Golconda & $196.1-73$ & 330 \\
\hline 24 & 10329000 & Little Humboldt River near Paradise Valley & $1922-28,1944-74$ & 340 \\
\hline 25 & 10329500 & Martin Creek near Paradise Valley & 1922-99 & 350 \\
\hline 26 & 10353000 & East Fork Quinn River near McDermitt & $1949-81$ & 360 \\
\hline 27 & 10353700 & Leonard Creek near Denio & $1961-83$ & 410 \\
\hline 28 & 10353750 & Mahogany Creek near Summit Lake & $1987-99$ & 420 \\
\hline 29 & 10353770 & South Willow Creek near Gerlach & 1973-99 & 430 \\
\hline 30 & 13161500 & Bruneau River at Rowland & 1913-18, 1967-99 & 440 \\
\hline 31 & - & East Stewart Creek near lone & $1987-92$ & 450 \\
\hline
\end{tabular}

${ }^{a}$ Fragmentary record. 


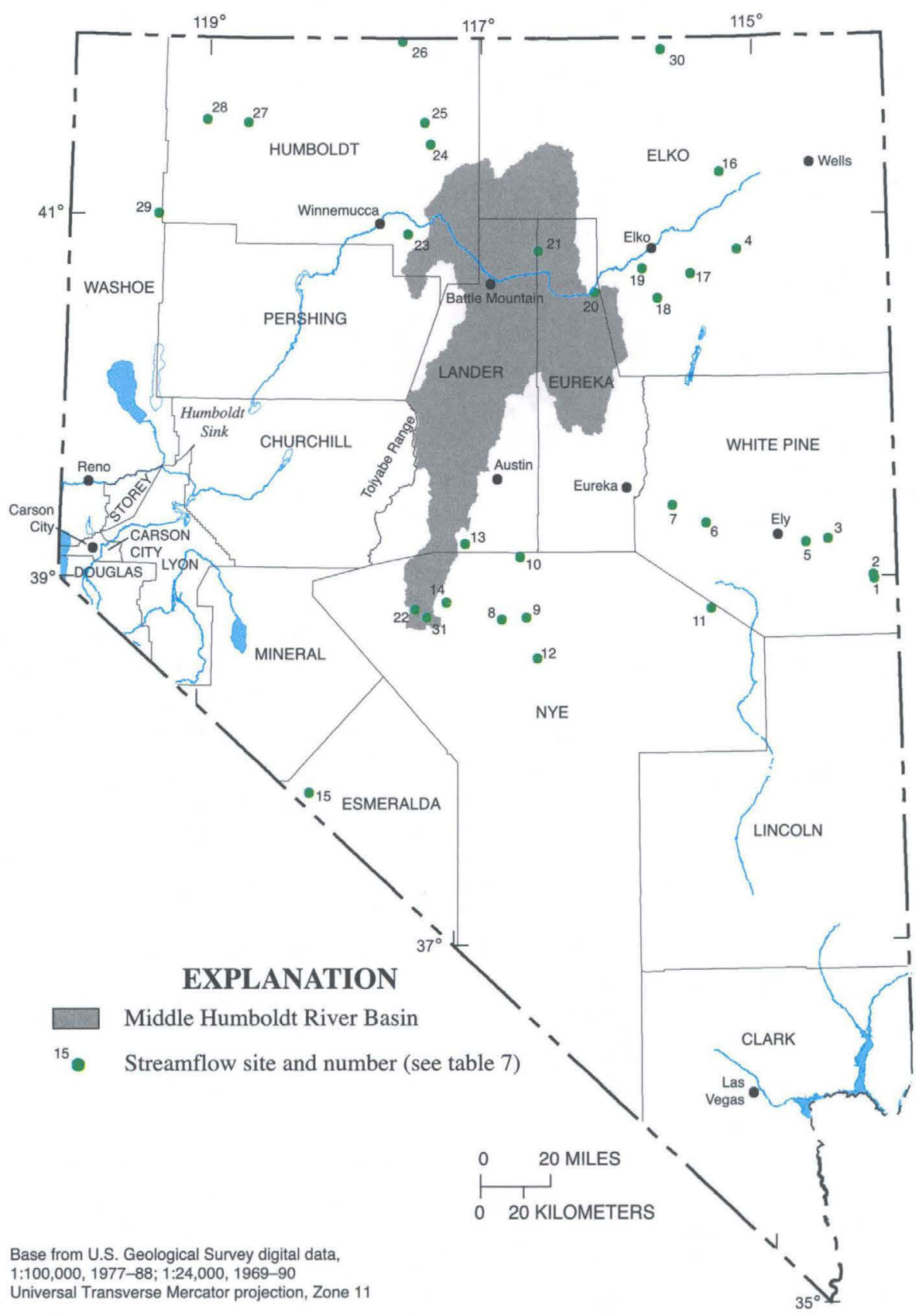

Figure 3. Location of selected streamflow gaging stations in north-central Nevada. Statistical analysis of records for these stations was to develop estimated 1944-99 streamflow of seven tributaries of the middle Humboldt River. 
table 5. The percent exceedences of the flow duration curves for the three index stations were computed based on a statistical analysis of available monthly data for each station. Monthly streamflows are defined as the average streamflow for any given month. Streamflows that were exceeded $1,5,10,25,50,75,90,95$, and 99 percent of the time were computed; these are listed in table 6 .

Duration curves at the 31 gaged tributary streams were determined from continuous streamflow data for sites near the Humboldt River Basin (for site locations, see fig. 3 and table 7). Stations used had at least 5 years of record available between 1944 and 1999, although some stations did not have a complete record for all months. The period of record for all stations did not necessarily overlap. Listed in table 6 are monthly streamflow-duration data for each of the 31 gaged tributary sites.

Basin characteristics for the middle Humboldt River tributaries (table 8) were measured on USGS topographic maps. Total drainage area of the tributary was determined by methods described by Cartier and others (1994) using GIS data bases with basin boundaries identified on 1:24,000-scale topographic maps. Latitude and longitude at the tributary mouth were measured from USGS topographic maps.

Basin and climatic characteristics were measured at each of the 31 gaged tributary sites. Drainage area, latitude and longitude, and elevation at the site were determined from USGS topographic maps. Mean annual precipitation was the basin average precipitation as determined from GIS methods summarizing the distribution of precipitation simulated by the Parameter-Elevation Regressions on Independent Slopes Model (PRISM) developed by the Oregon Climate Service (G.H. Taylor, Oregon State Climatologist, written commun., May 1997). Mean basin altitude was determined by GIS methods using elevation data from 1-degree DEM (Digital Elevation Model) (U.S. Geological Survey, 1995). The stream length was the distance in miles along the main channel from the gaging station to the basin divide as measured on the maps. The channel slope was measured between points that are 10 percent and 85 percent of the main channel length upstream from the study site. Percentages of each basin above $6,000 \mathrm{ft}, 8,000 \mathrm{ft}$, and $10,000 \mathrm{ft}$, respectively, were determined from GIS methods. A qualitative variable indicating the exposure (north, south, east, or west) of the drainage area was included in the analysis to determine if a rain-shadow effect was discernible. The measured physical and climatic characteristics associated with each station are listed in table 8 .

In general terms, a multiple-regression analysis was used to derive estimating regression equations in the form:

$$
Q_{x x}=a A^{b} B^{c} \ldots
$$

where:

$Q_{x x}$ is the monthly streamflow with a percent

$$
\text { exceedence probability of } \mathrm{xx} \text {; }
$$

$A$ and $B$ are the basin physical and climatic characteristics; and

$a, b$, and $c$ are the regression coefficients.

For the middle Humboldt River, monthly streamflow-duration data and basin physical and climatic characteristics at the 31 gaged sites were transformed to logarithms. Monthly streamflows for each percent exceedence level of $1,5,10,25,50,75,90,95$, and 99 percent (nine different levels) were related to the basin and climatic characteristics using the multiple-regression procedure (SAS Institute, 1995, p. 440). The multiple regression evaluates each independent variable in turn and includes the variable in the final regression equation if its use significantly improves the data fit.

Several statistics were used to identify the presence of outliers in the streamflow data for the 31 basins. These statistics included the hat matrix, studentized residual, covariance ratio matrix, Cook's D-test, and PRESS statistic (SAS Institute, 1999, p. 1418-19, and Helsel and Hirsch, 1997, p. 247-250). These statistics indicated that two sites had outlier data. One of the sites is the Newark Valley tributary near Hamilton because it has long periods of no flow. The other site is the South Fork Humboldt River near Elko because flow at this site greatly exceeds flow at the other sites. Data for these two sites were removed from the subsequent statistical analysis.

The results of the multiple-regression analyses for the remaining 29 gaged basins indicate that drainage area and latitude are the best descriptors for estimating monthly streamflow characteristics. Two statistics, coefficient of determination $\left(\mathrm{r}^{2}\right)$ and the standard error of estimate, were used to evaluate the reliability of the derived equations. The coefficient of determination ranged from 0.07 to 0.95 and the average was 0.55 . The standard error of estimate of the relations ranged from 81 to 144 percent and the average was 103 percent. 
Table 8. Selected basin physical and climatic characteristics of gaged tributary streams in north-central Nevada

\begin{tabular}{|c|c|c|c|c|c|c|c|c|c|c|c|c|c|}
\hline $\begin{array}{l}\text { Station } \\
\text { number }\end{array}$ & Station name & $\begin{array}{c}\text { Drainage } \\
\text { area }\end{array}$ & $\begin{array}{c}\text { Gage } \\
\text { altitude } \\
\text { (feet above } \\
\text { sea level) }\end{array}$ & $\begin{array}{c}\text { Main } \\
\text { channel } \\
\text { slope (feet } \\
\text { per mile) }\end{array}$ & $\begin{array}{l}\text { Mean basin } \\
\text { altitude (feet } \\
\text { above sea } \\
\text { level) }\end{array}$ & $\begin{array}{l}\text { Stream } \\
\text { length } \\
\text { (miles) }\end{array}$ & $\begin{array}{l}\text { Annual } \\
\text { precipitation } \\
\text { (inches) }\end{array}$ & Aspect & $\begin{array}{l}\text { Latitude } \\
\text { (mouth) } \\
\text { (decimal } \\
\text { degrees) }\end{array}$ & $\begin{array}{c}\text { Longitude } \\
\text { (mouth) } \\
\text { (decimal } \\
\text { degrees) }\end{array}$ & $\begin{array}{c}\text { Percentage } \\
\text { of basin } \\
\text { above } \\
6,000 \text { feet }\end{array}$ & $\begin{array}{c}\text { Percentage } \\
\text { of basin } \\
\text { above } \\
8,000 \text { feet }\end{array}$ & $\begin{array}{c}\text { Percentage } \\
\text { of basin } \\
\text { above } \\
10,000 \text { feet }\end{array}$ \\
\hline 10243240 & Baker Creek at Narrows, near Baker & 16.6 & 6,750 & 236 & 9,506 & 6.9 & 26.5 & east & 40.56 & 114.96 & 100 & 86 & 36 \\
\hline 10243260 & Lehman Creek near Baker & 8.9 & 6,730 & 496 & 9,788 & 5.92 & 28.2 & east & 39.011 & 114.21 & 100 & 89.6 & 48.7 \\
\hline 10243700 & Cleve Creek near Ely & 31.4 & 6,200 & 270 & 8,951 & 7.89 & 23.7 & east & 39.216 & 114.529 & 100 & 74.7 & 22.3 \\
\hline 10244720 & Franklin River near Arthur & 10.5 & 6,567 & 588 & 8,109 & 5.76 & 31.5 & south & 40.824 & 115.136 & 100 & 49 & 3.2 \\
\hline 10244950 & Steptoe Creek near Ely & 10.8 & 7,440 & 369 & 8,969 & 5.92 & 24 & north & 39.201 & 114.69 & 100 & 90.3 & 13.3 \\
\hline 10245445 & Illipah Creek near Hamilton & 30.7 & 6,840 & 138 & 7,847 & 8.81 & 15.9 & north & 39.319 & 115.394 & 100 & 38.8 & 0 \\
\hline 10245800 & Newark Valley tributary near Hamilton & 157.2 & 6,120 & 21 & 6,859 & 16.18 & 13.2 & south & 39.417 & 115.631 & 100 & 9.1 & .1 \\
\hline 10245900 & Pine Creek near Belmont & 12.1 & 7,560 & 720 & 9,842 & 5 & 21.9 & east & 39.794 & 116.854 & 100 & 98 & 45.6 \\
\hline 10245910 & Mosquito Creek near Belmont & 15 & 7,200 & 447 & 9,415 & 7.85 & 17.3 & west & 38.806 & 116.679 & 100 & 94.9 & 23.1 \\
\hline 10245925 & Stoneberger Creek near Austin & 35.8 & 6,880 & 204 & 8,415 & 12.55 & 16.9 & east & 39.14 & 116.721 & 100 & 72.1 & .3 \\
\hline 10246846 & Little Currant Creek near Currant & 12.6 & 6,700 & 491 & 8,381 & 5.43 & 16.6 & south & 38.847 & 115.367 & 100 & 57.5 & 7.6 \\
\hline 10249190 & Willow Creek near Warm Springs & 16.5 & 6,800 & 160 & 7,844 & 6 & 9.83 & south & 38.576 & 116.601 & 100 & 35.6 & 0 \\
\hline 10249280 & $\begin{array}{l}\text { Kingston Creek below Cougar Canyon } \\
\text { near Austin }\end{array}$ & 23.4 & 6,480 & 113 & 8,595 & 8.29 & 19.5 & east & 39.213 & 117.113 & 100 & 75.5 & 6.1 \\
\hline 10249300 & South Twin River near Round Mountain & 19.3 & 6,400 & 604 & 8,985 & 8.1 & 19.3 & east & 38.888 & 117.244 & 100 & 86.2 & 11.9 \\
\hline 10249900 & Chiatovich Creek near Dyer & 36.1 & 6,350 & 307 & 9,912 & 8.68 & 13.9 & east & 37.833 & 118.203 & 100 & 86.6 & 45.5 \\
\hline 10315500 & $\begin{array}{l}\text { Marys River above Hot Springs Creek } \\
\text { near Deeth }\end{array}$ & 390.1 & 5,500 & 37 & 6,603 & 44.2 & 15.9 & south & 41.253 & 115.256 & 75.6 & 6.6 & 0 \\
\hline 10316500 & Lamoille Creek near Lamoille & 24.9 & 6,240 & 270 & 8,976 & 9.86 & 31.4 & west & 40.69 & 115.476 & 100 & 80.2 & 15.8 \\
\hline 10319500 & Huntington Creek near Lee & 784.5 & 5,315 & 11 & 6,393 & 58 & 14.6 & north & 40.563 & 115.717 & 54.8 & 7.2 & .4 \\
\hline 10320500 & South Fork Humboldt River near Elko & 1,290 & 5,100 & 110 & 6,327 & 31.6 & 14.9 & north & 40.724 & 115.829 & 47.7 & 8.3 & .8 \\
\hline 10323000 & Pine Creek near Palisade & 1,002 & 4,900 & 24 & 6,202 & 66.1 & 12.8 & north & 40.595 & 116.174 & 52 & 1.7 & 0 \\
\hline 10324500 & Rock Creek near Battle Mountain & 864 & 4,670 & 24 & 5,732 & 55.2 & 11.7 & south & 40.824 & 116.584 & 24.6 & 0.4 & 0 \\
\hline 10325500 & Reese River near Ione & 53.8 & 7,100 & 180 & 8,768 & 13.45 & 17.2 & west & 38.85 & 117.467 & 100 & 77.5 & 10.7 \\
\hline 10328000 & Pole Creek near Golconda & 10.3 & 4,920 & 531 & 6,861 & 5.52 & 16.3 & north & 40.914 & 117.531 & 81.5 & 14.6 & 0 \\
\hline 10329000 & Little Humboldt River near Paradise Valley & 995 & 4,470 & 23 & 5,572 & 57.2 & 15 & west & 41.415 & 117.373 & 21.6 & .1 & 0 \\
\hline 10329500 & Martin Creek near Paradise Valley & 175 & 4,700 & 633 & 6,223 & 23.67 & 22.5 & south & 41.533 & 117.428 & 56 & 1.9 & 0 \\
\hline 10353000 & East Fork Quinn River near McDermitt & 137 & 4,700 & 68 & 6,089 & 23.8 & 22.8 & west & 41.983 & 117.583 & 56.4 & 0 & 0 \\
\hline 10353700 & Leonard Creek near Denio & 50.8 & 4,300 & 230 & 6,161 & 10.42 & 13.5 & south & 41.528 & 118.713 & 51.1 & 7 & 0 \\
\hline 10353750 & Mahogany Creek near Summit Lake & 13.3 & 6,080 & 307 & 7,301 & 5.68 & 8.5 & west & 41.542 & 119.015 & 100 & 100 & 7.4 \\
\hline 10353770 & South Willow Creek near Gerlach & 31.3 & 4,500 & 165 & 5,826 & 10.89 & 13.3 & south & 41.018 & 119.351 & 29.7 & .3 & 0 \\
\hline 13161500 & Bruneau River at Rowland & 380.6 & 4,500 & 63 & 6,711 & 44.2 & 18.5 & north & 41.933 & 115.674 & 90.7 & 4.6 & 0 \\
\hline- & East Stewart Creek near Ione & .36 & 9,455 & 1,590 & 10,170 & .85 & 25.2 & west & 38.89 & 117.36 & 100 & 100 & 66.7 \\
\hline
\end{tabular}


Neither of the statistical measures is acceptable. Therefore, residual values, computed as the difference between measured and computed flows, were evaluated to determine whether factors other than drainage area and latitude influence the outcome of the regression analysis. The evaluation of residual values indicate that a single set of regression equations developed for 29 basins in central and northern Nevada will not provide adequate estimates of tributary inflow to the middle Humboldt River. One reason for this is that basin latitude may not completely account for basin location in the regression equations. The equations produce more-accurate estimates when the basins are closely grouped rather than widespread. Another rea- son is that large basins, especially those of several hundred square miles or more, have flow characteristics that differ from those of smaller basins. Consequently, each of the seven tributaries that provide inflow to the middle Humboldt River was grouped into one of four regions. For each of these tributaries, either the streamflow-duration or index-station method was used to estimate flow to the middle Humboldt River when gaging-station data are available.

The streamflow-duration method was used for region 1, which includes the basins of Susie, Maggie, Marys, and Woodruff Creeks (pl. 1; table 9). The coefficient of determination for the nine equations ranges from 0.17 to 0.94 and the average is 0.59 .

Table 9. Regression equations used to determine monthly tributary inflow in the middle Humboldt River Basin for use when gaging-station data are unavailable

[Symbols: $\mathrm{Q}_{\mathrm{X}}$, monthly streamflow for percent of time exceeded, in cubic feet per second; A, drainage area, in square miles; Lat, latitude in decimal degrees at the mouth of the basin; $Q_{\text {all }}$, monthly discharge for all flows; $Q_{\text {martin }}$, monthly discharge for station 10329500 (Martin Creek near Paradise Valley); $Q_{\text {rock }}$, monthly discharge for station 10324500 (Rock Creek near Battle Mountain); -, no value determined]

\begin{tabular}{|c|c|c|}
\hline Humboldt tributary basin & $\begin{array}{l}\text { Regression equation used } \\
\text { to estimate streamflows }{ }^{1}\end{array}$ & $\begin{array}{c}\text { Coefficient of } \\
\text { determination }\left(r^{2}\right)\end{array}$ \\
\hline \multirow{9}{*}{$\begin{array}{l}\text { Susie Creek } \\
\text { Maggie Creek } \\
\text { Marys Creek } \\
\text { Woodruff Creek } \\
\text { (Region 1) }\end{array}$} & $Q_{1}=A^{-0.04}((\text { Lat }-28) / 10)^{-3.27}$ & 0.17 \\
\hline & $Q_{5}=A^{0.05}\left((\text { Lat-28)/10 })^{-2.05}\right.$ & .25 \\
\hline & $\mathrm{Q}_{10}=\mathrm{A}^{0.11}((\text { Lat }-28) / 10)^{-1.68}$ & .23 \\
\hline & $\mathrm{Q}_{25}=\mathrm{A}^{0.22}((\text { Lat }-28) / 10)^{-0.97}$ & .28 \\
\hline & $\mathrm{Q}_{50}=\mathrm{A}^{0.32}((\text { Lat }-28) / 10)^{0.22}$ & .68 \\
\hline & $\mathrm{Q}_{75}=\mathrm{A}^{0.42}((\mathrm{Lat}-28) / 10)^{2.91}$ & .89 \\
\hline & $\mathrm{Q}_{90}=\mathrm{A}^{0.53}\left((\text { Lat-28)/10 })^{5.14}\right.$ & .93 \\
\hline & $\mathrm{Q}_{95}=\mathrm{A}^{0.61}\left((\text { Lat-28)/10 })^{5.56}\right.$ & .94 \\
\hline & $\mathrm{Q}_{99}=\mathrm{A}^{0.76}((\mathrm{Lat}-28) / 10)^{5.79}$ & .94 \\
\hline Pine Creek (Region 2) & $Q_{\text {all }}=-31.6+2.26 Q_{\text {rock }}+0.89 Q_{\text {martin }}$ & .88 \\
\hline \multirow[t]{9}{*}{ Rock Creek (Region 3) } & $\mathrm{Q}_{1}=\mathrm{A}^{-1.10}((\text { Lat }-28) / 10)^{23.2}$ & .36 \\
\hline & $\mathrm{Q}_{5}=\mathrm{A}^{-0.90}((\text { Lat }-28) / 10)^{21.8}$ & .37 \\
\hline & $\mathrm{Q}_{10}=\mathrm{A}^{-0.74}((\text { Lat }-28) / 10)^{20.2}$ & .58 \\
\hline & $\mathrm{Q}_{25}=\mathrm{A}^{-0.40}((\text { Lat }-28) / 10)^{15.3}$ & .89 \\
\hline & $Q_{50}=A^{-0.18}\left(\left(\right.\right.$ Lat-28)/10) ${ }^{13.5}$ & .97 \\
\hline & $\mathrm{Q}_{75}=\mathrm{A}^{-0.07}\left((\text { Lat-28)/10) })^{15.4}\right.$ & .98 \\
\hline & $\mathrm{Q}_{90}=\mathrm{A}^{-0.02}((\text { Lat }-28) / 10)^{17.9}$ & .98 \\
\hline & $\mathrm{Q}_{95}=\mathrm{A}^{0.14}\left((\text { Lat-28)/10 })^{15.9}\right.$ & 99 \\
\hline & $Q_{99}=A^{0.33}\left(\left(\right.\right.$ Lat-28)/10) ${ }^{13.7}$ & .99 \\
\hline Reese River (Region 4) & $\mathrm{Q}_{\mathrm{all}}=32.4+0.14 \mathrm{Q}_{\text {rock }}+0.74 \mathrm{Q}_{\text {martin }}$ & .77 \\
\hline
\end{tabular}


Several different regression equations using the streamflow-duration method were determined for region 2, the Pine Creek basin, from different combinations of basin and climatic characteristics. However, none produced satisfactory results. Consequently, the index-station method was used to relate monthly flow of Pine Creek measured near Palisade during the 194658 water years to streamflow at the two index gaging stations, Rock Creek near Battle Mountain and Martin Creek near Paradise Valley (pl. 1). The results of this regression analysis produced a coefficient of determination of 0.88 (table 9).

The streamflow-duration method was used to estimate streamflow from region 3, Rock Creek. The nine equations in table 9 were developed by relating streamflow-duration data to basin and climatic characteristics for basins with drainage areas larger than 350 $\mathrm{mi}^{2}$ (table 8). The Rock Creek basin has a drainage area of $875 \mathrm{mi}^{2}$. The statistical measure of the resulting regression equation had an coefficient of determination ranging from 0.36 to 0.99 and the average was 0.79 .

The mouth of the Reese River is about $13 \mathrm{mi}$ northwest of Battle Mountain between the Battle Mountain and Comus stream gaging stations (pl. 1). Streamflow of the Reese River at its mouth has never been regularly measured, mainly because flows of the river cease as much as $60 \mathrm{mi}$ south of Battle Mountain in most water years. According to Eakin and Lamke (1966, p. 36), the Reese River flows into the Humboldt River on average about once every 15 years. Horton (2000, p. I-53) also states that the Reese River contributes to the surface-water flow of the Humboldt River only during severe rain-on-snow events or in years of heavy snowpack. A compilation of flood data dating from 1861 indicates that the Reese River has flowed at flood stage to the Battle Mountain area about 9 times in 101 years (U.S. Soil Conservation Service, 1962). Most of these floods occurred between January and July.

Two conditions seem to help define whether the Reese River has flowed into the Humboldt River during the January through June period of any given water year. First, the flow of the Humboldt River increases between the Battle Mountain and Comus gaging stations. The second condition is that flow of the Humboldt River at Battle Mountain exceeds $400 \mathrm{ft}^{3} / \mathrm{s}$. Thus, gaging-station records for the Humboldt River are used to determine the timing of flow of the Reese River at its mouth. Monthly streamflow gains of $40 \mathrm{ft}^{3} / \mathrm{s}$ or more between the Battle Mountain and Comus gaging stations occurred 12 times during the period 1944-99. Streamflow gains of less than $40 \mathrm{ft}^{3} / \mathrm{s}$ are not considered to be useful because of the uncertainties associated with the records for the Battle Mountain and Comus gaging stations. The 12 monthly gains were related by regression analysis to corresponding monthly streamflow at two index gaging stations, Rock Creek and Martin Creek. The coefficient of determination for the regression equation is 0.77 .

In summary, flows of the seven tributaries that enter the middle Humboldt River are based on: (1) measured flows for any periods during which a gaging station was active on the tributary, and (2) estimated flows determined from regression equations (table 9) during periods when gaging station records are not available. The monthly time series of tributary inflows for 1944-99 then were apportioned to each model reach according to where the tributary flows into the Humboldt River. The tributary, model reach, and ANNIE data-set number are given in table 5 .

\section{Mine-Dewatering Inflows}

Three of the mines being dewatered in the study area must release part of this water either to the Humboldt River or to two of its tributaries (for mine and site locations, see pl. 1). Water from the Gold Quarry Mine (inflow range of 0 to $44 \mathrm{ft}^{3} / \mathrm{s}$ ) is released to Maggie Creek several miles above its mouth. Water from the Betze Mine (flow range from 0 to $145 \mathrm{ft}^{3} / \mathrm{s}$ ) was released in 1998-99 to the Humboldt River between Dunphy and Argenta. Finally, water from the Lone Tree Mine (site 11, flow range from 0 to $73 \mathrm{ft}^{3} / \mathrm{s}$ ) is released to the Iron Point Relief Canal. Water from this canal enters Herrin Slough, which enters the Humboldt River just upstream from the Comus gaging station (site 12). Records of these releases, maintained by mining companies, were used to develop time-series data sets. These surface-water inflows to the river then were distributed to the appropriate model reach (table 10). 
Table 10. Mine-dewatering inflows to the middle Humboldt River used in the flow-routing and operations modules

[No station numbers were assigned to these stations]

\begin{tabular}{cccc}
\hline $\begin{array}{c}\text { Site no. } \\
\text { (model } \\
\text { reach) } \\
\text { (see pl. 1) }\end{array}$ & Station name & $\begin{array}{c}\text { Period of } \\
\text { record } \\
\text { (water } \\
\text { year) }\end{array}$ & $\begin{array}{c}\text { ANNIE } \\
\text { data-set } \\
\text { number }\end{array}$ \\
\hline $3(1)$ & Gold Quarry mine inflows & $1994-99$ & 235 \\
$6(7)$ & Betze mine inflows & $1997-99$ & 285 \\
$11(11)$ & Lone Tree mine inflows & $1992-99$ & 325 \\
\hline
\end{tabular}

\section{Ground-Water Gains and Losses}

In the middle Humboldt River Basin, interactions between ground water and surface water are both significant and complex. Depending on the time of year and stage of the river, ground-water seepage can result in flow gains along some reaches of the river, and infiltration to underlying aquifers can result in flow losses along other reaches. Using only the streamflow data from gaging stations to estimate flow gains or losses can be difficult because the stations are too far apart to adequately define these gains or losses. For the model, more accurate gain or loss estimates were made from water-balance computations that used streamflow data from synoptic investigations. These data were collected by the USGS as part of several studies in the water years of 1964-66 (Eakin and Lamke, 1966), 1989-93 (Plume, 1995; and Maurer and others, 1996) and 1999_ 2000 (current study) on various reaches in the middle Humboldt River. All of these synoptic data are accessible on the Internet at <http://nevada.usgs.gov/humb $>$. Streamflows measured during these synoptic investigations varied from 14 to $2,890 \mathrm{ft}^{3} / \mathrm{s}$ at the Humboldt River at Palisade gaging station.

In the model, flow gain and loss estimates were made using the results from synoptic investigations supplemented with streamflow data from gaging stations. The magnitude, timing, and distribution of gains and losses varied with the stage of the river. Estimates of flow gains and losses (table 11) were applied to each river reach in the flow-routing module. Gains were as much as $80 \mathrm{ft}^{3} / \mathrm{s}$ and losses as much as $400 \mathrm{ft}^{3} / \mathrm{s}$.

\section{Assumptions Made to Simulate Streamflow Using Flow-Routing Module}

The following assumptions were made to simplify construction of the flow-routing module:
- Monthly tributary inflows to the middle

Humboldt River can be estimated on the basis of basin latitude and area and on measured monthly streamflow data if the streamflow-duration method is used, or on nearby index gaging stations. Average hydraulic properties of the river did not change from 1944 to 1999.

- Direct evaporation from and precipitation to the Humboldt River were assumed to be negligible.

\section{Operations Module Used in Middle Humboldt River Model}

Ditch headgates along the middle Humboldt River are operated according to the Bartlett and Edwards decrees, which specify conditions for use of the water. Conditions that were used to develop the monthly operations module included time of year an irrigation diversion can be used, streamflow magnitude at a given location, and fulfillment of water demands and irrigation return flow simulation.

\section{Data and Logic Needed to Construct the Operations Module}

\section{Irrigation Diversions}

According to Hennen (1964a; 1964b), streamflow diverted for irrigation purposes must be measured where the main ditch enters or becomes adjacent to the land being irrigated. The amount of water diverted from the river can exceed the amount actually used because of infiltration losses along the ditch between the diversion and point of use. The NDWR and USGS have made a few flow measurements on the several irrigation ditches along the middle Humboldt River. However, continuous flow data on irrigation ditches are not available.

To simulate irrigation diversions, the middle Humboldt River operations module used conditional logic that compares the flow at the upstream boundary of each reach to the total demand, dictated by water rights, that could be satisfied. For ditches within a reach, demand (stated in terms of flow per day) was determined using total decreed water and the ditch capacities. The agricultural demand capable of being satisfied under river flow conditions is diverted from the main stem to the appropriate ditch. This demand 
Table 11. Estimates of ground-water gain or loss, by reach, used in the middle Humboldt River model

\begin{tabular}{|c|c|c|}
\hline $\begin{array}{l}\text { Model reach } \\
\text { (pl. 1) }\end{array}$ & $\begin{array}{l}\text { Ground-water gain or loss, related to flow at } \\
\text { Humboldt River at Palisade (cubic feet per second) }\end{array}$ & $\begin{array}{l}\text { ANNIE data-set } \\
\text { number }\end{array}$ \\
\hline 1 & $\begin{array}{l}\text { River flow less than } 65-\text { gain }=10.5 \\
\text { River flow greater than } 65 \text {, but less than } 150-\text { loss }=4 \\
\text { River flow greater than } 150 \text {, but less than } 435-\text { loss }=22 \\
\text { River flow greater than } 435 \text {, but less than } 2900-\text { gain }=80\end{array}$ & 9401 \\
\hline 2 & $\begin{array}{l}\text { River flow less than } 65-\text { gain }=3.2 \\
\text { River flow greater than } 65 \text {, but less than } 150-\text { gain }=18 \\
\text { River flow greater than } 150 \text {, but less than } 435-\text { gain }=32 \\
\text { River flow greater than } 435 \text {, but less than } 2900-\text { gain }=80\end{array}$ & 9402 \\
\hline 3 & $\begin{array}{l}\text { River flow less than } 65-\text { gain }=10.8 \\
\text { River flow greater than } 65 \text {, but less than } 150-\text { loss }=22 \\
\text { River flow greater than } 150 \text {, but less than } 435-\text { gain }=18 \\
\text { River flow greater than } 435 \text {, but less than } 2900-\text { loss }=229\end{array}$ & 9403 \\
\hline 4 & $\begin{array}{l}\text { River flow less than } 65-\text { gain }=0.7 \\
\text { River flow greater than } 65 \text {, but less than } 150-\text { loss }=0 \\
\text { River flow greater than } 150 \text {, but less than } 435-\text { loss }=29 \\
\text { River flow greater than } 435 \text {, but less than } 2900-\text { loss }=251\end{array}$ & 9404 \\
\hline 5 & $\begin{array}{l}\text { River flow less than } 65-\text { loss }=3 \\
\text { River flow greater than } 65 \text {, but less than } 150-\text { loss }=8 \\
\text { River flow greater than } 150 \text {, but less than } 435-\text { gain }=22 \\
\text { River flow greater than } 435 \text {, but less than } 2900-\text { loss }=90\end{array}$ & 9405 \\
\hline 6 & $\begin{array}{l}\text { River flow less than } 65-\text { loss }=7.1 \\
\text { River flow greater than } 65 \text {, but less than } 150-\text { loss }=39 \\
\text { River flow greater than } 150 \text {, but less than } 435-\text { gain }=8 \\
\text { River flow greater than } 435 \text {, but less than } 2000-\text { gain }=48 \\
\text { River flow greater than } 2000 \text {, but less than } 2400-\text { loss }=200 \\
\text { River flow greater than } 2400 \text {, but less than } 4500-\text { loss }=400\end{array}$ & 9406 \\
\hline 7 & $\begin{array}{l}\text { River flow less than } 65-\text { loss }=11.9 \\
\text { River flow greater than } 65 \text {, but less than } 150-\text { gain }=18 \\
\text { River flow greater than } 150 \text {, but less than } 435-\text { loss }=14 \\
\text { River flow greater than } 435 \text {, but less than } 2900-\text { loss }=250\end{array}$ & 9407 \\
\hline 8 & $\begin{array}{l}\text { River flow less than } 65-\text { loss }=0.2 \\
\text { River flow greater than } 65 \text {, but less than } 150-\text { gain }=5 \\
\text { River flow greater than } 150 \text {, but less than } 435-\text { gain }=7 \\
\text { River flow greater than } 435 \text {, but less than } 2000-\text { gain }=57 \\
\text { River flow greater than } 2000 \text {, but less than } 4500-\text { loss }=400\end{array}$ & 9408 \\
\hline 9 & $\begin{array}{l}\text { River flow less than } 65-\text { loss }=2.2 \\
\text { River flow greater than } 65 \text {, but less than } 150-\text { loss }=2 \\
\text { River flow greater than } 150 \text {, but less than } 435-\text { loss }=14 \\
\text { River flow greater than } 435 \text {, but less than } 1000-\text { loss }=98 \\
\text { River flow greater than } 1000 \text {, but less than } 4500-\text { loss }=400\end{array}$ & 9409 \\
\hline 10 & $\begin{array}{l}\text { River flow less than } 65-\text { loss }=6.0 \\
\text { River flow greater than } 65 \text {, but less than } 150-\text { loss }=21 \\
\text { River flow greater than } 150 \text {, but less than } 435-\text { loss }=6 \\
\text { River flow greater than } 435 \text {, but less than } 800-\text { loss }=100 \\
\text { River flow greater than } 800 \text {, but less than } 5000-\text { loss }=200\end{array}$ & 9410 \\
\hline 11 & $\begin{array}{l}\text { River flow less than } 65-\text { loss }=2.1 \\
\text { River flow greater than } 65 \text {, but less than } 150-\text { loss }=5 \\
\text { River flow greater than } 150 \text {, but less than } 435-\text { gain }=26\end{array}$ & 9411 \\
\hline 12 & All river flows - gain $=2.2$ & 9412 \\
\hline
\end{tabular}


varies from month to month according to percentages of ditch capacity, which change monthly during the irrigation season.

In the model, the beginning date of the irrigation season, as defined in Mashburn and Mathews (1943, p. $28-30$ ), is always March 15. The ending date of the season and the number of irrigations depends on the average March-July flow of the Humboldt River at Palisade for each year. Average March-through-July flows of the river at Palisade were $869 \mathrm{ft}^{3} / \mathrm{s}$ during water years 1944-99. The standard deviation, a statistical measure of the year-to-year variance of this average flow, is $369 \mathrm{ft}^{3} / \mathrm{s}$. These two numbers were used by the model to categorize each year (1944-99) as wet, dry, or average. If average March-July streamflow for a specific year was greater than the mean flow for the 1944 99 period plus one-half the standard deviation, the year was considered wet. If average March-July streamflow for any year was less than the mean minus one-half the standard deviation, the year was considered dry. Using these flows at Palisade, the model simulated four irrigations if a year was categorized as average or wet and only two irrigations if a year was categorized as dry. Irrigation diversions simulated by the model ranged from 0 to $250 \mathrm{ft}^{3} / \mathrm{s}$.

Figure 4 shows two graphs. The top graph shows average monthly flow of the Humboldt River at Palisade during the 1985 irrigation season. The lower graph shows diversions to the White House Ditch at Dunphy during the 1985 irrigation season and the relation of the diversion to flow in the river at Palisade. Conditional logic in the operations module determines the timing and extent to which agricultural irrigation demands and others on the middle Humboldt River are satisfied. In April 1985, Humboldt River flows of about $900 \mathrm{ft}^{3} / \mathrm{s}$ at Palisade were sufficient to satisfy all water rights for White House Ditch. Accordingly, the full water right of about $29 \mathrm{ft}^{3} / \mathrm{s}$ was being diverted. In May, June, and August, no water was diverted to White House Ditch because other rights were being satisfied. In July and September 1985, Humboldt River flow at Palisade was reduced, thus lesser percentages (50 and 20 percent, respectively) of the full water rights in White House Ditch were available and the diversions were reduced to about 14 and $7 \mathrm{ft}^{3} / \mathrm{s}$, respectively.

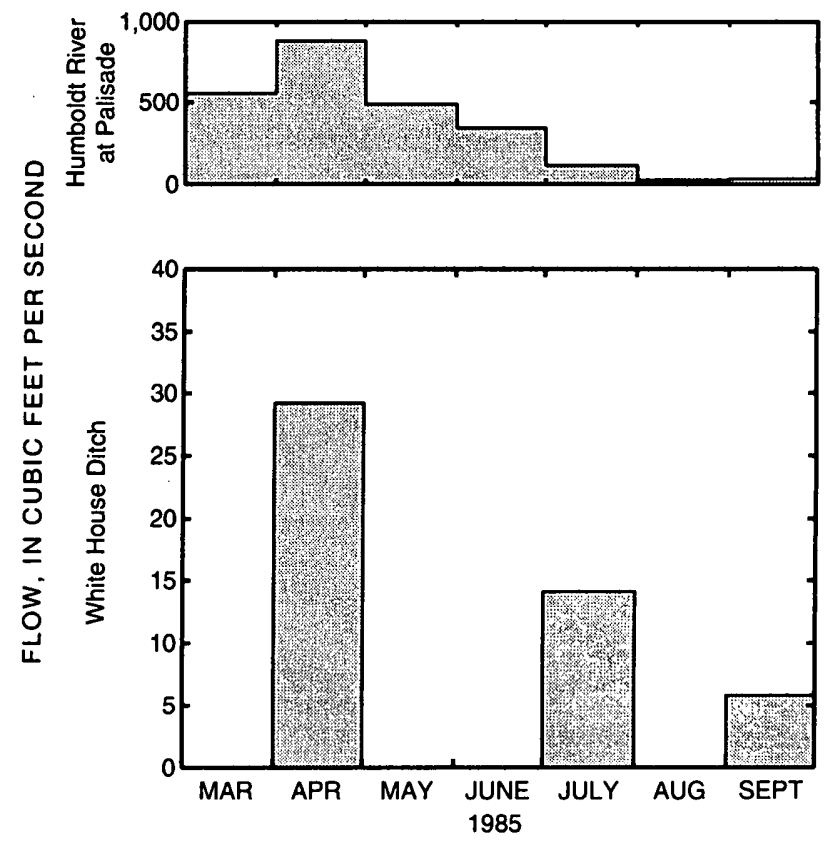

Figure 4. Relation of streamflow diverted at White House Ditch in the 1985 irrigation season to concurrent flow of the Humboldt River at Palisade, Nevada.

\section{Irrigation Return Flow}

Mashburn and Mathews (1943, p. 30) describe irrigation return flows to the Humboldt River as being available to meet downstream irrigation demand. However, irrigation return flows on the Humboldt River have never been quantified. In practice, return flows may be used on the next field downgradient so that several fields may be irrigated from a single diversion.

\section{Assumptions Made to Simulate Diversions and Return Flows}

The following assumptions were made for simulating diversions and return flows in constructing the operations module.

- The model simulates diversions to each ditch as a continuous, average amount for each day that Humboldt River water is available throughout the irrigation season. Actual irrigation practices use water in a more cyclical manner. For example, fields might be flood-irrigated for a period of days or weeks with an amount of water larger than the 
constant amount simulated by the model. However, because neighboring users probably stagger ditch withdrawals for lands served by the same ditch, the total volume diverted to any given ditch over a period of several days was assumed to be the same as that produced by the "average diversion" simulated by the model.

- Streamflow of the Humboldt River at Palisade provides an index for estimating ending date of the irrigation season.

- The operations module determines the amount of irrigation return flows based on the amount of water diverted. The assumption is that a percentage of water diverted on any given model reach returns to the next reach downstream. Simulated return flows are varied as follows: 50 percent of the diversion during the first irrigation of the season, 20 percent during the second irrigation, and 10 percent for any irrigation thereafter. Simulated irrigation return flows ranged from 0 to $125 \mathrm{ft}^{3} / \mathrm{s}$.

- Stockwater diversions were not simulated and were assumed to be negligible compared with irrigation diversions.

- The maximum flow capacity of ditches was assumed to be the value provided by the NDWR (Wayne Testolin, written commun., 2000).

\section{SIMULATION OF STREAMFLOW USING SURFACE-WATER MODEL}

Model simulations of middle Humboldt River streamflow were made by applying measured and estimated inflow and outflow time-series and observed data for water years 1944-99 to conditional logic in the HSPF SPECL block. The ability of the model to simulate monthly mean streamflow was tested by qualitatively comparing streamflow measured at several gaging stations with streamflow simulated at the station. Differences between simulated and observed streamflows undoubtedly resulted from uncertainties in the estimates used to characterize inflow to and outflow from the middle Humboldt River. Each of the individual inflow and outflow components of the hydrologic system was tested to determine the sensitivity of the model to each component.
Each water year in the Humboldt River Basin can be characterized as wet, average, or dry based on the flow record for the Palisade gaging station (see "Irrigation Diversions" section). The model was used to simulate monthly flow during water years that represent each of these conditions. Observed and simulated monthly flow of the Humboldt River at Palisade, Battle Mountain, and Comus are shown as graphs in figures 5-7 for a wet year (1998), an average year (1964), and a dry year (1977), respectively.

Results from model simulations generally agree with the timing and magnitude of observed monthly flows at each of the three gaging stations. Differences between simulated and observed flows appear to increase downstream, especially for wet and average conditions. This is probably the result of increased model uncertainty. As more inflows and outflows are simulated, any associated uncertainties may be compounded. Thus, simulated flows at Palisade correspond more closely with observed flows than at Comus. This is especially evident in the wet year of 1998 .

Monthly flows at all three stations (figs. 5-7) are undersimulated during late winter, spring, and early summer during wet conditions (1998) and in late winter and spring during average and dry conditions (1964 and 1977, respectively). This undersimulation of streamflow when the stage of the Humboldt River is rising may be a result of overestimates of streamflow infiltration or flood plain roughness, underestimates of tributary inflow, or a combination.

Comparison of simulated flows with observed flows in the summers of 1998 and 1964 (wet and average conditions, respectively) indicates that flows are underestimated in some months and overestimated in others. These differences may be due to combination of uncertainties inherent to estimates of model inflows and outflows.

The model consistently oversimulates flows at the three gaging stations during the summer of 1977 (fig. 7). This oversimulation of flow when the stage of the Humboldt River is falling during a dry year may be a result of overestimation of tributary inflow or of ground-water seepage to the river channel, underestimation of the roughness of the low-flow channel, or a combination of the three. 

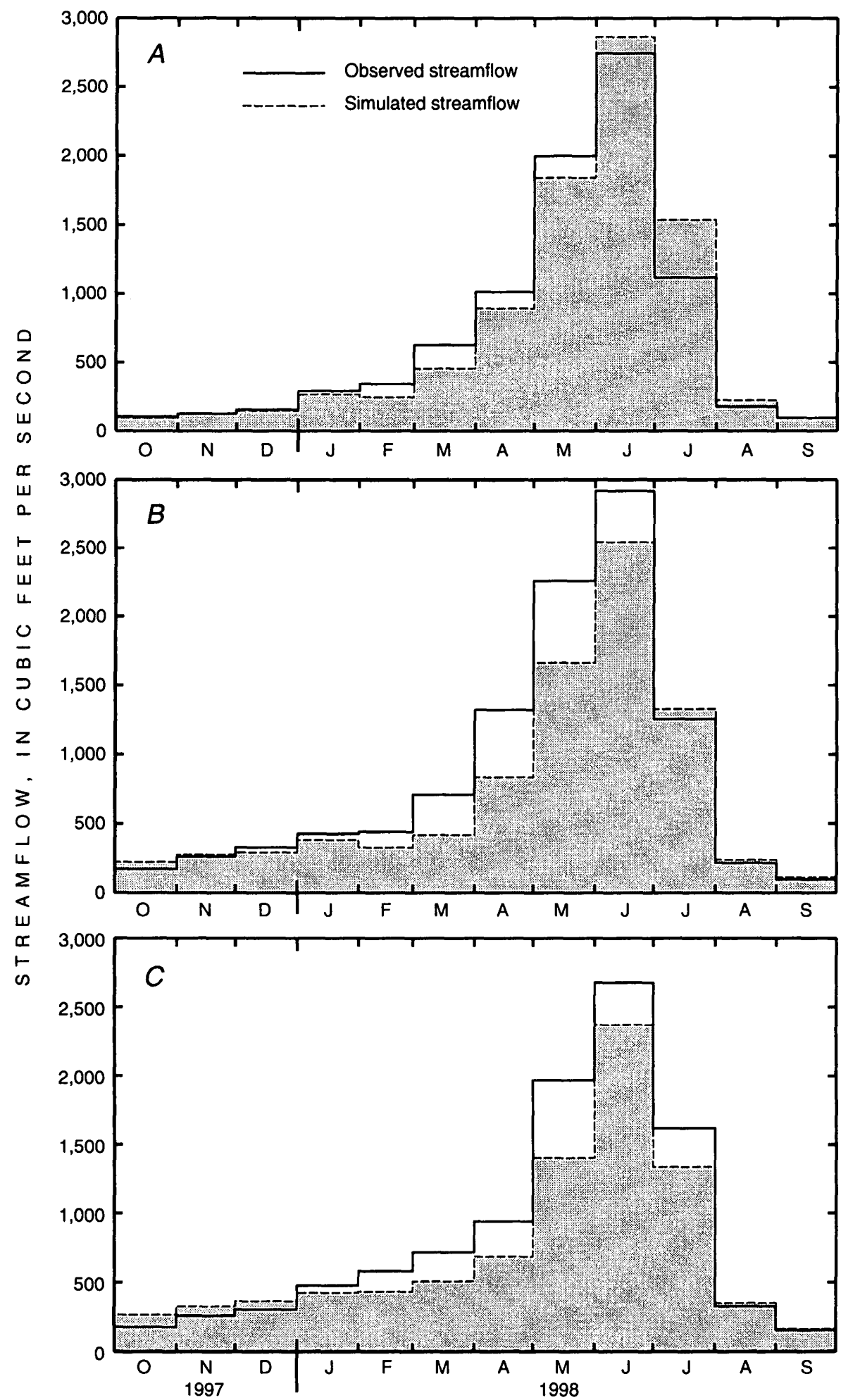

Figure 5. Observed streamflow and simulated monthly mean streamflow of the Humboldt River in a wet year (water year 1998) at (A) Palisade, (B) Battle Mountain, and $(C)$ Comus. 


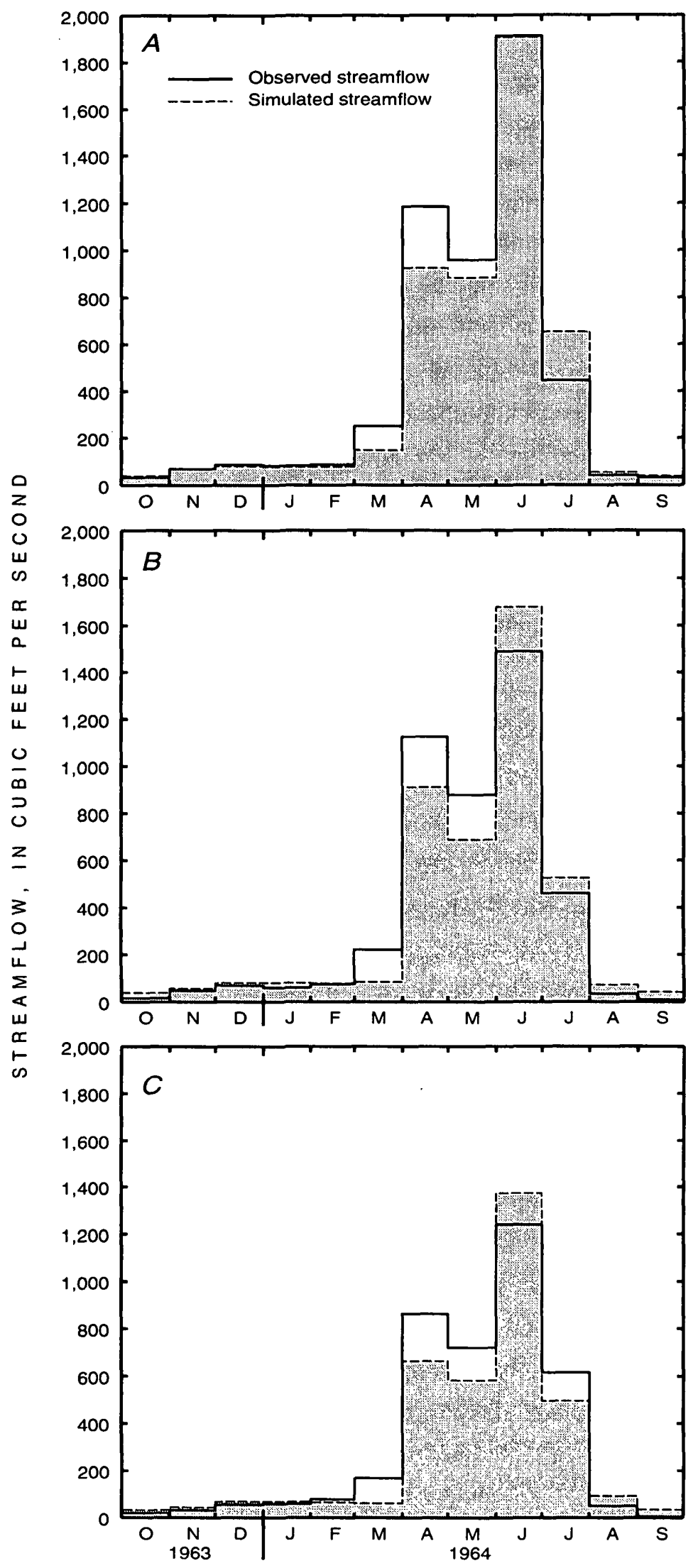

Figure 6: Observed flow and simulated monthly mean streamflow of the Humboldt River in an average year (water year 1964) at (A) Palisade, $(B)$ Battle Mountain, and $(C)$ Comus. 

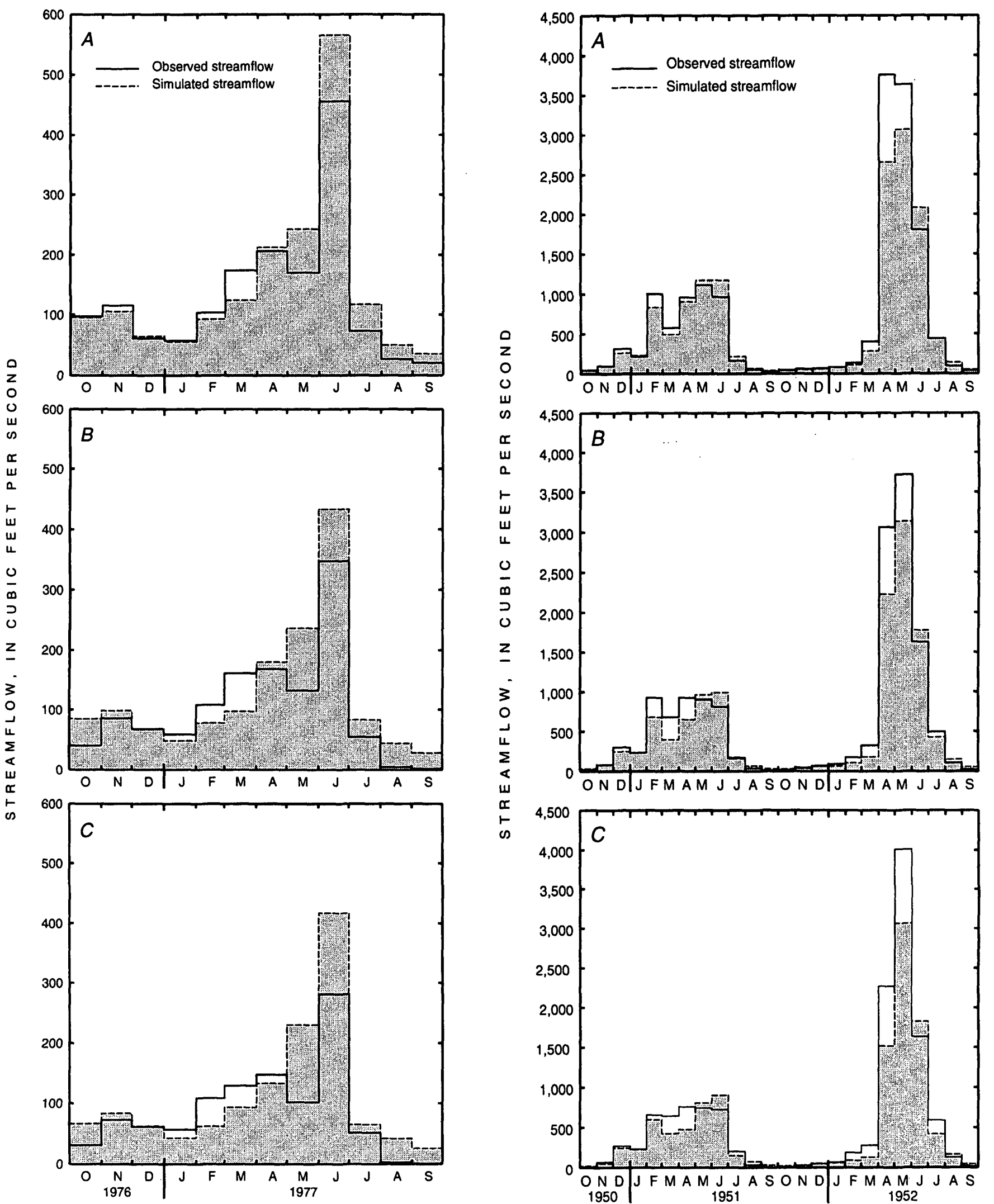

Figure 7. Observed and simulated monthly mean streamflow of the Humboldt River in a dry year (water year 1977) at (A) Palisade, (B) Battle Mountain, and (C) Comus. monthly mean streamflow of the Humboldt River in successive average and wet years (water years 1951 and 1952) at $(A)$ Palisade, $(B)$ Battle Mountain, and $(C)$ Comus. 
Table 12. Relation of simulated monthly mean streamflow at Palisade, Battle Mountain, and Comus stream-gaging stations to changes in components of flow-routing and operations modules

[Abbreviation: $\mathrm{ft}^{3} / \mathrm{s}$, cubic feet per second]

\begin{tabular}{|c|c|c|c|}
\hline $\begin{array}{l}\text { Model reach } \\
\text { (pl. 1) }\end{array}$ & Location name & Multiplication factor and component & Average flow $\left(\mathrm{ft}^{3} / \mathrm{s}\right)^{1}$ \\
\hline \multirow[t]{20}{*}{3} & \multirow[t]{20}{*}{ Humboldt River at Palisade } & Variable $\mathrm{KS}=0.0$ & 422 \\
\hline & & Variable $\mathrm{KS}=0.5$ & 423 \\
\hline & & Variable $\mathrm{KS}=0.55$ & 436 \\
\hline & & 0.5 times model reach area and volume & 424 \\
\hline & & 1.0 times model reach area and volume & 423 \\
\hline & & 0.0 times mine dewatering flows & 420 \\
\hline & & 1.0 times mine dewatering flows & 423 \\
\hline & & 2.0 times mine dewatering flows & 425 \\
\hline & & 0.0 times tributary inflows & 383 \\
\hline & & 1.0 times tributary inflows & 423 \\
\hline & & 2.0 times tributary inflows & 464 \\
\hline & & 0.5 times ground-water gains/losses & 422 \\
\hline & & 1.0 times ground-water gains/losses & 423 \\
\hline & & 2.0 times ground-water gains/losses & 429 \\
\hline & & 0.0 times irrigation diversions & 428 \\
\hline & & 1.0 times irrigation diversions & 423 \\
\hline & & 2.0 times irrigation diversions & 418 \\
\hline & & 0.0 times irrigation diversions returns & 422 \\
\hline & & 1.0 times irrigation diversions returns & 423 \\
\hline & & 2.0 times irrigation diversions returns & 424 \\
\hline \multirow[t]{20}{*}{8} & \multirow[t]{20}{*}{ Humboldt River at Battle Mountain } & Variable $\mathrm{KS}=0.0$ & 375 \\
\hline & & Variable $\mathrm{KS}=0.5$ & 373 \\
\hline & & Variable $\mathrm{KS}=0.55$ & 382 \\
\hline & & 0.5 times model reach area and volume & 373 \\
\hline & & 1.0 times model reach area and volume & 373 \\
\hline & & 0.0 times mine dewatering flows & 370 \\
\hline & & 1.0 times mine dewatering flows & 373 \\
\hline & & 2.0 times mine dewatering flows & 377 \\
\hline & & 0.0 times tributary inflows & 305 \\
\hline & & 1.0 times tributary inflows & 373 \\
\hline & & 2.0 times tributary inflows & 444 \\
\hline & & 0.5 times ground-water gains/losses & 408 \\
\hline & & 1.0 times ground-water gains/losses & 373 \\
\hline & & 2.0 times ground-water gains/losses & 323 \\
\hline & & 0.0 times irrigation diversions & 394 \\
\hline & & 1.0 times irrigation diversions & 373 \\
\hline & & 2.0 times irrigation diversions & 359 \\
\hline & & 0.0 times irrigation diversions returns & 371 \\
\hline & & 1.0 times irrigation diversions returns & 373 \\
\hline & & 2.0 times irrigation diversions returns & 377 \\
\hline
\end{tabular}


Table 12. Relation of simulated monthly mean streamflow at Palisade, Battle Mountain, and Comus stream-gaging stations to changes in components of flow-routing and operations modules-Continued

\begin{tabular}{|c|c|c|c|}
\hline $\begin{array}{l}\text { Model reach } \\
\text { (pl. 1) }\end{array}$ & Location name & Multiplication factor and component & Average flow $\left(\mathrm{ft}^{3} / \mathrm{s}\right)^{1}$ \\
\hline \multirow[t]{20}{*}{11} & Humboldt River near Comus & Variable $\mathrm{KS}=0.0$ & 337. \\
\hline & & Variable $\mathrm{KS}=0.5$ & 335 \\
\hline & & Variable $\mathrm{KS}=0.55$ & 342 \\
\hline & & 0.5 times model reach area and volume & 334 \\
\hline & & 1.0 times model reach area and volume & 335 \\
\hline & & 0.0 times mine dewatering flows & 325 \\
\hline & & 1.0 times mine dewatering flows & 335 \\
\hline & & 2.0 times mine dewatering flows & 346 \\
\hline & & 0.0 times tributary inflows & 271 \\
\hline & & 1.0 times tributary inflows & 335 \\
\hline & & 2.0 times tributary inflows & 403 \\
\hline & & 0.5 times ground-water gains/losses & 388 \\
\hline & & 1.0 times ground-water gains/losses & 335 \\
\hline & & 2.0 times ground-water gains/losses & 264 \\
\hline & & 0.0 times irrigation diversions & 365 \\
\hline & & 1.0 times irrigation diversions & 335 \\
\hline & & 2.0 times irrigation diversions & 318 \\
\hline & & 0.0 times irrigation diversions returns & 331 \\
\hline & & 1.0 times irrigation diversions returns & 335 \\
\hline & & 2.0 times irrigation diversions returns & 340 \\
\hline
\end{tabular}

${ }^{1}$ Comparison period of model simulations is water years 1944-99.

\section{MODEL TESTING AND SENSITIVITY ANALYSIS}

The middle Humboldt River streamflow model is based on estimated monthly time-series data that represent all inflows and outflows, and on model parameters that represent hydraulic characteristics of the river channel along 12 reaches. If these inflow and outflow data and model parameters are adequately characterized, then streamflow should be accurately simulated. A sensitivity analysis of several of the model components was used to show if streamflow is adequately simulated by the model. The following sections describe various components of this analysis: (1) testing of the surface-water model; (2) sensitivity analysis of various components of the model; (3) limitations of the model; and (4) suggestions for improving the model.

\section{Model Testing}

Model simulations must be tested against observed streamflow data before the model can be relied upon to estimate conditions along the middle
Humboldt River. The model was tested by examining the difference between observed and simulated streamflow as related to the hydraulic properties of the middle Humboldt River defined in the FTABLE block.

During the modeling process, hydraulic properties in the FTABLE block were not changed because they represent physical properties of the river channel and adjacent floodplain that were determined from field surveys. Comparison of simulated monthly flow with observed flow in water years 1951-52 (fig. 8) provides a useful means of evaluating whether hydraulic properties in the FTABLE block adequately represent characteristics of the river channel and floodplain.

Hydrographs (figs. 8A-C) for three middle Humboldt River gaging stations (Palisade, Battle Mountain, and Comus) show that the timing of observed and simulated flow in the river for average conditions, water year 1951, and wet conditions, water year 1952, followed similar patterns. As observed streamflows rise or fall, simulated flows also rise or fall. Differences between observed and simulated flows range from 1 to 3 months. Differences between the magnitude of observed and simulated streamflow that extend for two or more months in figure 8 probably are due mostly to 
uncertain data for tributary inflows or ground-water gains or losses used as input to the model. Therefore, for this study, the FTABLE block was not adjusted.

\section{Sensitivity Analysis}

Another method to evaluate the soundness of a model is a sensitivity analysis of the model parameters. The Sensitivity Analyses of the hydraulic characteristics (KS and FTABLE) describe the, relative magnitude of each parameter.

Flow data such as mine-dewatering flows, tributary inflow, ground-water gain or loss, irrigation diversions, and irrigation return flows accounted for middle Humboldt River inflow and outflow time-series data. For water years 1944-99, sensitivity analyses were completed for each type of data. These analyses assessed the effects of errors in input parameters or estimates, within the range of those parameters examined, on the model results.

\section{Model Parameters}

In the sensitivity analysis of the variable $\mathrm{KS}$ were set at $0.0,0.5$, and 0.55 (table 12). Simulated average monthly flows of the Humboldt River at Palisade, Battle Mountain, and Comus using these $\mathrm{KS}$ values ranged from $422 \mathrm{ft}^{3} / \mathrm{s}$ to $436 \mathrm{ft}^{3} / \mathrm{s}, 373$ to $382 \mathrm{ft}^{3} / \mathrm{s}$, and 335 to $342 \mathrm{ft}^{3} / \mathrm{s}$, respectively. This analysis indicates that the model is not excessively sensitive to changes in $\mathrm{KS}$.

Previous studies have shown that the lengths of the Humboldt River channel and flood plain can vary by as much as 50 to 75 percent. Therefore, the channel length of the Humboldt River can be used as an indicator of model reach area and volume. A sensitivity analysis for 0.5 and 1.0 times the reach area and volume, as represented in the FTABLE block for 1944-99, shows that the average monthly flow at Humboldt River at Palisade, Battle Mountain, and Comus was $423 \mathrm{ft}^{3} / \mathrm{s}$, $373 \mathrm{ft}^{3} / \mathrm{s}$, and $335 \mathrm{ft}^{3} / \mathrm{s}$, respectively. This analysis indicates that reach area and volume has little effect on simulation of monthly streamflow (table 12).

Model testing indicates that the FTABLE and model parameter, KS, do adequately characterize Humboldt River hydraulics and that differences between observed and simulated streamflow result mostly from insufficient information to characterize inflows and outflows to the middle Humboldt River.

\section{Mine-Dewatering Inflows}

Variations of mine-dewatering inflows to the river by $0.0,1.0$, and 2.0 times (table 12 ) resulted in simulated average monthly flows at the Palisade, Battle Mountain, and Comus gaging stations that ranged from 420 to $425 \mathrm{ft}^{3} / \mathrm{s}, 370$ to $377 \mathrm{ft}^{3} / \mathrm{s}$, and 325 to $346 \mathrm{ft}^{3} / \mathrm{s}$, respectively. This analysis indicates that mine-dewatering inflow to the river has little effect on simulation of monthly streamflow at the two upstream sites, but has a more significant effect on model simulations at Comus. The analysis also indicates that mine-dewatering inflows have an increasing effect going downstream in simulation of middle Humboldt River monthly streamflow.

\section{Tributary Inflows}

Variations of tributary inflows to the river by 0.0 , 1.0 , and 2.0 times (table 12) resulted in simulated average monthly flows at the Palisade, Battle Mountain, and Comus gaging stations that ranged from 383 to 464 $\mathrm{ft}^{3} / \mathrm{s}, 305$ to $444 \mathrm{ft}^{3} / \mathrm{s}$, and 271 to $403 \mathrm{ft}^{3} / \mathrm{s}$, respectively. This analysis indicates that tributary inflow has an increasing effect going downstream in simulation of middle Humboldt River monthly streamflow and has a significant effect on model simulations.

\section{Ground-Water Gain or Loss}

Variations of ground-water gains or losses to the river by $0.5,1.0$, and 2.0 times (table 12 ) resulted in simulated average monthly flows at the Palisade, Battle Mountain, and Comus gaging stations that ranged from 422 to $429 \mathrm{ft}^{3} / \mathrm{s}, 408$ to $323 \mathrm{ft}^{3} / \mathrm{s}$, and 388 to $264 \mathrm{ft}^{3} / \mathrm{s}$, respectively. This analysis indicates that ground-water gain or loss increases going downstream and has a significant effect on model simulation.

The middle Humboldt River consistently gains flow as a result of ground-water seepage upstream from Palisade, and consistently loses flow as ground-water infiltration from Palisade to Comus (Maurer and others; 1996, p. 68). The sensitivity analysis suggests that the model is not very sensitive to variations in groundwater gains, but is sensitive to variations in infiltration losses. 


\section{Irrigation Diversions}

Variations of irrigation diversions from the river by $0.0,1.0$, and 2.0 times (table 12) resulted in simulated average monthly flows at the Palisade, Battle Mountain, and Comus gaging stations that ranged from 428 to $418 \mathrm{ft}^{3} / \mathrm{s}, 394$ to $359 \cdot \mathrm{ft}^{3} / \mathrm{s}$, and 365 to $318 \mathrm{ft}^{3} / \mathrm{s}$, respectively. This analysis indicates that irrigation diversions are important to simulation of monthly streamflow, and the effects are cumulative downstream.

\section{Irrigation Return Flows}

Variations of irrigation return flows to the river by $0.0,1.0$, and 2.0 times resulted in simulated flows of the river at Palisade, Battle Mountain, and Comus that ranged from 422 to $424 \mathrm{ft}^{3} / \mathrm{s}, 371$ to $377 \mathrm{ft}^{3} / \mathrm{s}$, and 331 to $340 \mathrm{ft}^{3} / \mathrm{s}$, respectively. This analysis indicates that irrigation return flow has little effect on simulation of monthly streamflow.

\section{Model Limitations}

Construction and testing of the surface-water model were subject to the following limitations:

- Data are unavailable to account for all inflows and outflows for the middle Humboldt River. Volume errors from this lack of data may be either compensating or cumulative. Therefore, the magnitude of simulation differences is not fully known.

- Only the surface-water part of mine-dewatering inflows is considered in reaches with mine-dewatering inflows. The effects of ground-water pumping and injection on streamflow are not addressed by this model.

- All historical diversions, both active and inactive, are simulated in the model, although three are no longer used because they were washed out before 2000. Any ditches or channels not mentioned in the Bartlett and Edwards Decrees are not simulated by the model. These include the Reese River channel, McIntyre and Herrin Sloughs, and the Iron Point Relief Canal.

\section{Model Improvements}

The middle Humboldt River surface-water model could be improved by:
- Integration of a ground-water model with the surface-water model. Better understanding of groundwater/surface-water interactions could provide better estimates of the gains and losses along the river channel.

- Measured inflows of principal middle Humboldt River tributaries, especially during periods of high spring runoff.

- Measured outflows of irrigation diversions during wet, dry, and average years.

\section{SUMMARY}

A surface-water computer model for the middle Humboldt River, from the Carlin gaging station to Preble, simulates monthly streamflow for water years 1944-99. This report: (1) briefly describes Humboldt River operational practices; (2) documents construction of a physically based middle Humboldt River model, including flow-routing and operations modules, data used to simulate flow routing, and the operational logic used and assumptions made; (3) compares observed and simulated streamflow; (4) tests hydrologic and hydraulic characterization of the middle Humboldt River; and (5) discusses model limitations and possible improvements. The surface-water model was constructed within a larger modeling system that includes ANNIE, a data-base management program, and HSPF, which simulates river operations and a variety of hydrologic processes.

The flow-routing module, which characterizes the movement of water into and through the reaches of the drainage network, must be used in combination with the operations module, which simulates the regulation of water within and out of the drainage network. The flow-routing module uses hydraulic characteristics derived from river data for 12 individual stream reaches in the study area. The model uses measured data such as flows recorded at four Humboldt River gaging stations and mine-dewatering inflows. Estimated tributary inflow, irrigation diversion outflow, irrigation return flows, and ground-water gain or losses also are used. Estimated flows in irrigation diversions are used to simulate operations of the middle Humboldt River. These operations are based on the Bartlett and Edwards Decrees, which adjudicate water rights in part of the basin.

Conditional logic, historic inflow data, and flow estimates for water years 1944-99 are applied to the operations model to simulate middle Humboldt River 
streamflow. Comparison of observed to simulated streamflows for monthly time periods indicates that differences between the two probably stems from uncertainties of estimates of tributary inflow, diversion outflow, and ground-water losses downstream from Palisade. Model testing shows that parameters adequately define physical characteristics of the middle Humboldt River channel and flood plain. Sensitivity analysis of the hydraulic model parameters, reach area and volume, shows that changes in reach length have a negligible effect on monthly flows simulated by the model. Sensitivity analysis of inflow and outflow components indicates that tributary inflows, irrigation diversions, and ground-water losses are significant components of the model, while mine dewatering and irrigation return flows are not. Thus, the model could be improved by: (1) additional gaging of tributaries and irrigation diversions, and (2) integration of the surfacewater model with a ground-water model to better define interactions between ground and surface water.

\section{REFERENCES CITED}

Berger, D.L., 1999, Water budgets for Pine Valley, Carico Lake Valley, and Upper Reese River Valley hydrographic areas, middle Humboldt River Basin, northcentral Nevada-Methods for estimation and results: U.S. Geological Survey Water-Resources Investigations Report 99-4272, 40 p.

2000, Water budgets estimates for the 14 hydrographic areas in the middle Humboldt River Basin, north-central Nevada: U.S. Geological Survey Water-Resources Investigations Report 00-4168, $55 \mathrm{p}$.

Bicknell, B.R., Imhoff, J.C., Kittle, J.L., Donigan, A.S., and Johanson, R.C., 1997, Hydrological simulation program-FORTRAN: User's manual for Version 11: U.S. Environmental Protection Agency, National Exposure Research Laboratory, EPA/600/R-97/080, 660 p.

Bohman, L.R., Berris, S.N., and Hess, G.W., 1995, Interactive computer program to simulate and analyze streamflow, Truckee and Carson River Basins, Nevada and California: U.S. Geological Survey Fact Sheet FS-165-95, 4 p.

Cardinalli, J.L., Roach, L.M., Rush, F.E., and Vasey, B.J., 1968, State of Nevada hydrographic areas: Nevada Division of Water Resources map, scale 1:500,000.

Cartier, K.D, Peltz, L.A., and Smith, J.L., 1994, Development and documentation of spatial data bases for the Lake Tahoe Basin, California and Nevada: U.S. Geological Survey Water-Resources Investigations Report 93-4182, $65 \mathrm{p}$.
Cohen, Philip, Hanson, R.L., Robinson, T.W., and Waananen, A.O., 1963, An evaluation of the water resources of the Humboldt River valley near Winnemucca, Nevada: Nevada Department of Conservation and Natural Resources, Water Resources Bulletin 24, $104 \mathrm{p}$.

Eakin, T.E., and Lamke, R.D., 1966, Hydrologic reconnaissance of the Humboldt River basin, Nevada: Nevada Department of Conservations and Natural Resources, Water Resources Bulletin 32, $107 \mathrm{p}$.

Helsel, D.R., and Hirsch, R.M., 1997, Statistical methods in water resources: Elsevier, 529 p.

Hennen, G.W., 1964a, Humboldt River water distribution, part 1-Problems: Nevada Division of Water Resources, unpaged.

1964b, Humboldt River water distribution, part 2Priority tables: Nevada Division of Water Resources, $183 \mathrm{p}$.

Hess, G.W., 1996, Progress report on daily flow-routing simulation for the Carson River, California and Nevada: U.S. Geological Survey Open-File Report 96-211, 41 p.

1999, Hydrologic data for water years 1978-97 used in daily flow-routing and river-operations models for the upper Carson River Basin, California and Nevada: U.S. Geological Survey Open-File Report 99-256, 16 p.

Hess, G.W., and Bohman, L.R., 1996, Techniques for estimating monthly mean streamflow at gaged sites and monthly streamflow duration characteristics at ungaged sites in central Nevada: U.S. Geological Survey OpenFile Report 96-559, 15 p.

Horton, Gary, 2000, Humboldt River chronology-An overview and chronological history of the Humboldt River and related water issues-Overview: Nevada Water Basin Information and Chronology Series, Nevada Division of Water Planning, unpaged.

Houghton, J.G., Sakamato, C.M., and Gifford, R.D., 1975, Nevada's weather and climate: Nevada Bureau of Mines and Geology Special Publication 2, 78 p.

Langbein, W.B., and Iseri, K.T., 1960, General introduction and hydrologic definitions: Manual of hydrology, Part 1 -General surface-water techniques: U.S. Geological Survey Water-Supply Paper 1541-A, 29 p.

Lumb, A.M., Kittle, J.L., and Flynn, K.M., 1990, Users manual for ANNIE, a computer program for interactive hydrologic analyses and data management: U.S. Geological Survey Water-Resources Investigations Report 89-4080, $236 \mathrm{p}$.

Mashburn, Gary, and Mathews, W.T., 1943, The Humboldt River adjudication 1923-38: Nevada State Printing Office, unpaged. 
Maurer, D.K., 1986, Geohydrology and simulated response to ground-water pumpage in Carson Valley, a riverdominated basin in Douglas County, Nevada, and Alpine County, California: U.S. Geological Survey Water-Resources Investigations Report 86-4328, 109 p.

Maurer, D.K., Plume, R.W., Thomas, J.M., and Johnson, A.K, 1996, Water resources and effects of changes in ground-water use along the Carlin Trend, north-central Nevada: U.S. Geological Survey Water-Resources Investigations Report 96-4134, 146 p.

Parrett, C. and Cartier, K.D., 1990, Methods for estimating monthly streamflow characteristics at ungaged sites in western Montana: U.S. Geological Survey Water-Supply Paper 2365, $30 \mathrm{p}$.

Plume, R.W., 1995, Water resources and potential effects of ground-water development in Maggie, Marys, and Susie Creek Basins, Elko and Eureka Counties, Nevada: U.S. Geological Survey Water-Resources Investigations Report 94-4222, $87 \mathrm{p}$.

Plume, R.W. and Ponce, D.A., 1999, Hydrogeologic framework and ground-water levels, 1982 and 1996, middle Humboldt River Basin, north-central Nevada: U.S. Geological Survey Water-Resources Investigations Report 98-4209, 2 p.

Regan, R.S., and Schaffranek, R.W., 1985, A computer program for analyzing channel geometry: U.S. Geological Survey Water-Resources Investigations Report 85-4335, $49 \mathrm{p}$.

Rush, F.E., 1968, Index of hydrographic areas in Nevada: Nevada Division of Water Resources, Information Report 6, 38 p.

SAS Institute, Inc., 1995, Basic statistics using SAS/STAT software: SAS Institute, $720 \mathrm{p}$. -1999, SAS/STAT User's Guide: Volume 2, GLMVARCOMP, Version 6, Fourth Edition, p. 891-1886.

U.S. Department of Army, Corps of Engineers, 1975, Hydrology-Humboldt River and tributaries, Nevada: Sacramento District, $50 \mathrm{p}$.

U.S. Geological Survey, 1995, Metadata for 1-degree Digital Elevation Models: U.S. Geological Survey, accessed November 8, 2000, at <http://nsdi.usgs.gov/wais/ maps/dem 1deg.html>.

U.S. Soil Conservation Service, 1962, Humboldt River Basin chronology of flood years and high water years June 1962, Special Report, 46 p.

Warmath, Eric, and Medina, R.L., 2001, Humboldt River Mainstem, Nevada [online]: U.S. Geological Survey metadata file available on the World Wide Web at <http://water.usgs.gov/GIS/metadata/usgswrd/ hdrmain_hum.html>.

\section{GLOSSARY}

Some of the technical terms and acronyms used in this report are defined for convenience of the reader. See Langbein and Iseri (1960) for additional information regarding hydrologic terminology.

ANNIE. The time-series data-management system that includes file creation, data management, analysis, and display.

CGAP. Channel Geometry Analysis Program.

Duration curve. A cumulative frequency curve that shows the percentage of time that specified discharges are equaled or exceeded.

DEM. Digital Elevation Model.

ET. Evapotranspiration.

FTABLE. HSPF block that specifies fixed relations among depth, surface area, volume, and discharge for a river reach.

GIS. Geographic information systems.

HSPF. Hydrological Simulation Program-FORTRAN.

HYDR. HSPF block that simulates unsteady flow by representing physical processes using the modified kinematic-wave algorithm.

Irrigation return flow. Excess irrigation water not consumptively used that returns to the main stem (or a collection ditch) from surface runoff, subsurface underflow, or ground-water inflows.

Irrigation season. Usually the 6-month period beginning March 15 and ending September 15 of any given year.

KS. In the flow-routing block of HSPF, a variable that is a weighting factor not physically measurable that influences the timing of flow and varies from 0.0 to 1.0 .

Monthly streamflow. The average streamflow for any given month.

NDWR. Nevada Division of Water Resources.

Observed data. A water data base generated from continuous or intermittent streamflow gaging-station data.

PRISM. Parameter-Elevation Regressions on Independent Slopes Model.

RCHRES. HSPF block called reach reservoir that simulates processes within a single reach.

Reach. A zone between two points along the river having relatively uniform hydraulic properties and used within HSPF to simulate the movement of water in, out, and along a river channel system.

SPECL. HSPF block called SPECiaL actions that permits the user to simulate operations using conditional logic.

Stockwater diversions. Irrigation diversion outside the irrigation season to provide water for livestock.

Streamflow station. A site where a continuous record of discharge is obtained. Within the U.S. Geological Survey, the term is used only for station where a continuous record of discharge is obtained. 
Synoptic investigations. Serial, nearly concurrent streamflow measurements along the length of the river to determine areas or points of gain or loss along a river.

UCI. User's Control Input.

USGS. U.S. Geological Survey.

Water year. The 12-month period beginning October 1 and ending September 30, and designated by the calendar year in which the water year ends.

WDM. Watershed Data Management file used by ANNIE to store data from HSPF. 

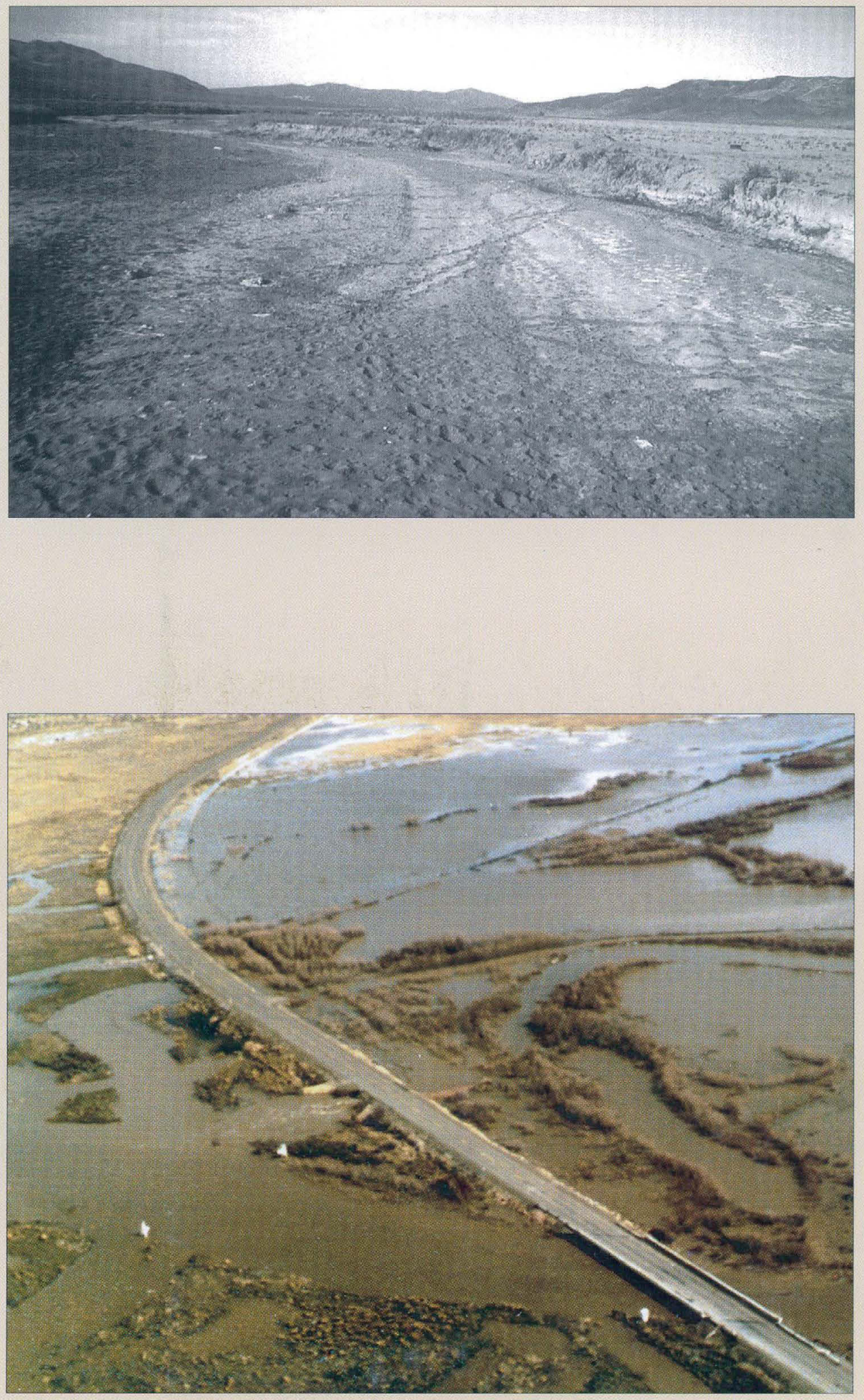

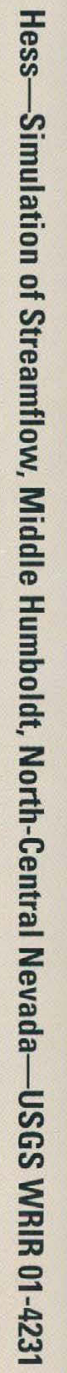

